\title{
The Distribution and Composition Characteristics of Siliceous Rocks from Qinzhou Bay-Hangzhou Bay Joint Belt, South China: Constraint on the Tectonic Evolution of Plates in South China
}

\author{
Hongzhong Li, ${ }^{1,2}$ Mingguo Zhai, ${ }^{1}$ Lianchang Zhang, ${ }^{1}$ Yongzhang Zhou, ${ }^{2,3}$ Zhijun Yang, ${ }^{2,3}$ \\ Junguo He, ${ }^{2,3}$ Jin Liang, ${ }^{2,3}$ and Liuyu $\mathrm{Zhou}^{2,3}$ \\ ${ }^{1}$ Key Laboratory of Mineral Resource, Institute of Geology and Geophysics, Chinese Academy of Science, Beijing 100029, China \\ ${ }^{2}$ Guangdong Provincial Key Lab of Geological Processes and Mineral Resource Survey, Guangzhou 510275, China \\ ${ }^{3}$ Department of the Earth Science of Sun Yat-sen University, Guangzhou 510275, China
}

Correspondence should be addressed to Hongzhong Li; lihongzhong01@aliyun.com and Zhijun Yang; 306147828@qq.com

Received 26 June 2013; Accepted 4 August 2013

Academic Editors: N. Hirao, S. Lucas, K. Nemeth, and G. Zhao

Copyright (C) 2013 Hongzhong Li et al. This is an open access article distributed under the Creative Commons Attribution License, which permits unrestricted use, distribution, and reproduction in any medium, provided the original work is properly cited.

\begin{abstract}
The Qinzhou Bay-Hangzhou Bay joint belt is a significant tectonic zone between the Yangtze and Cathaysian plates, where plentiful hydrothermal siliceous rocks are generated. Here, the authors studied the distribution of the siliceous rocks in the whole tectonic zone, which indicated that the tensional setting was facilitating the development of siliceous rocks of hydrothermal genesis. According to the geochemical characteristics, the Neopalaeozoic siliceous rocks in the north segment of the Qinzhou Bay-Hangzhou Bay joint belt denoted its limited width. In comparison, the Neopalaeozoic Qinzhou Bay-Hangzhou Bay joint belt was diverse for its ocean basin in the different segments and possibly had subduction only in the south segment. The ocean basin of the north and middle segments was limited in its width without subduction and possibly existed as a rift trough that was unable to resist the terrigenous input. In the north segment of the Qinzhou Bay-Hangzhou Bay joint belt, the strata of hydrothermal siliceous rocks in Dongxiang copper-polymetallic ore deposit exhibited alternative cycles with the marine volcanic rocks, volcanic tuff, and metal sulphide. These sedimentary systems were formed in different circumstances, whose alternative cycles indicated the release of internal energy in several cycles gradually from strong to weak.
\end{abstract}

\section{Introduction}

The Qinzhou Bay-Hangzhou Bay joint belt (QHJB), located between the Yangtze and Cathaysian plates, has attracted much attention because of its interesting tectonic properties. The QHJB is a long, narrow tectonic zone that is shaped like a reversed letter S [1]. It starts from Hangzhou Bay in northeastern Zhejiang province, spanning Zhejiang, Jiangxi, Hunan, Guangdong, and Guangxi provinces, and ends at Qinzhou Bay in the south of Guangxi province. A large amount of research on the QHJB has examined different aspects of its tectonic properties, such as the Caledonian fold belt [2-4], arc-trench system [5-7], melange zone [8], Jiangnan inland orogenic belt [4], South China orogenic belt [9], middle Jiangxi collisional zone [10], South China collisional orogen [11-13], terrane [14], Qinzhou-Hangzhou tectonic joint belt [1], and even the mantle plume structure $[15,16]$. Thus far, the orogen properties of the QinzhouHangzhou joint belt $[4,13,17-20]$ have been confirmed by the discovery of ophiolite suites [21-23]. These ophiolite suites are distributed in the areas of Fuchan [24-26] and northeast Jiangxi province $[27,28]$ in the northern segment, areas of northern Guangxi province and western Hunan province [29] in the middle segment, and areas of west Guangdong province [23] and Luchuan [30,31] in the southern segment. The majority ages of the ophiolite suites lie within the range from $860 \mathrm{Ma}$ to $1030 \mathrm{Ma}[31,32]$, which indicate, without doubt, Mesoproterozoic and Neoproterozoic orogens for the tectonic properties of the QHJB possibly related to the evolution of the Rodinia supercontinent. The orogen 
properties of the QHJB remained until the Silurian period [33] and ended with the collisional matching of the Yangtze and Cathaysian plates due to Caledonian movement [34].

The Neopalaeozoic tectonic properties of QHJB have puzzled researchers, and major controversies exist in regard to the existence of an ocean basin with subduction. In published papers, the Neopalaeozoic ophiolitic melange in northeast Jiangxi province possibly indicates the Qinzhou-Hangzhou tectonic zone to be the eastern part of the Neopalaeozoic Tethys ocean [28], and the early Mesozoic acid volcanic rocks of the south segment in southwest Guangxi province confirm the subduction of an ocean basin until the middle Triassic period [35]. Although there is diversity among the north, middle, and south segments [36-38], the QHJB exhibits integral uniformity in its tectonic evolution $[36,39]$. Therefore, the tectonic properties of the QHJB were proposed to be an orogen in the Neopalaeozoic by the current authors [28, 35]. The Qin-Fang trough has been attested in the south segment $[40,41]$, but there is a lack of orogenic properties because of the absence of a homochronous ophiolite suite and volcanic rocks in the middle and north segments [31]. This indicates that the Neopalaeozoic tectonic properties for the entire $\mathrm{QHJB}$ remain somewhat unclear, and the orogenic properties may not possibly run throughout the whole QHJB with subduction in the ocean basin. In addition, the QHJB possibly underwent rifting in the NE direction in the Devonian and early Permian and then experienced folding and orogeny due to the compression of Dongwu movement [33]. The tectonic properties of the QHJB remain unclear in the Hercynian.

The distribution, composition, and microfabric characteristics are significant for understanding the geological properties of the QHJB. In the literature, the geologic setting and geographic framework can be proposed using siliceous rocks for its geochemical characteristics [42-44], which helps underpin the tectonic framework with siliceous rocks widely [45-47]. In the QHJB, the siliceous rocks are distributed widely [38] and indicate hydrothermal genesis $[28,40,48-50]$ and can possibly contribute to understanding the geological properties of the QHJB. Although these previous studies examined some individual cases, rarely has attention been given to the temporal and spatial distribution of siliceous rocks in the entirety of the QHJB. In the QHJB, the siliceous rocks have complex tectonic evolution [38], and they potentially preserve significant evidence that will aid in the comprehension and understanding of tectonic properties. Thus, the distributions of siliceous rocks in the entirety of the QHJB were examined in this study to determine the tectonic significance of the siliceous rocks. In addition, geological analysis, X-ray diffraction (XRD), scanning electron microscopy (SEM), and energy dispersive spectrometry (EDS) were also adopted for analysis of the Neopalaeozoic siliceous rocks. These analyses aided in understanding the geological characteristics and associated indications.

\section{Geological Setting and Petrological Characteristics}

2.1. Geological Setting. The Mesoproterozoic South China block (also named as Elder South China block) is distributed

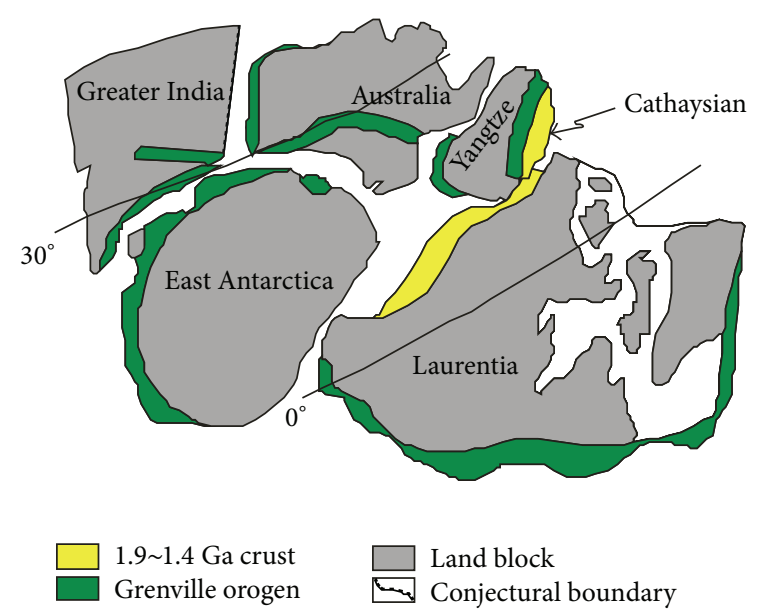

FIGURE 1: Location of South China block in north late Mesoproterozoic Rodinia supercontinent (after [54]).

among three land blocks (Figure 1), which are named EastAustralia, Antarctica, and Laurentia, respectively. The Elder South China block is originated from the matching of Yangtze and Cathaysian blocks, whose crystalline basement is formed in diverse geological era. In the previous study, the ancient land crusts of Yangtze and Cathaysian are, respectively, formed in the Neoarchean and Paleoproterozoic [51]. The formation of the Yangtze ancient land crust is attested to be in Neoarchean as evidenced by the crystalline basement of the Neoarchean to Paleoproterozoic [52]. The Cathaysian ancient land crust is a group of similar crusts including Yunkai, Mintai, and Wuyi platforms and is formed at the end of the Paleoproterozoic (1800 Ma) for the Paleoproterozoic crystalline basement [51]. These two blocks are cohered together possibly due to the Lüliang movement, which is witnessed by the Lüliangian granite in southwest Zhejiang province [34]. With the matching of Yangtze and Cathaysian blocks, the Elder South China block [53] is formed at the end of late Paleoproterozoic [33]. Then, the whole Elder South China block was covered by a uniform sedimentary veneer.

The QHJB comes from the fragmentation of the Elder South China block at the beginning of the Mesoproterozoic. There is a fragmentation period after Lüliang movement with rift troughs, and this fragmentation contributes to the primary ocean basin of QHJB which separates the Yangtze block from Cathaysian block. After its formation, the QHJB undergoes cyclic tectonic movements, which is possibly associated with the evolution of the Rodinia supercontinent. During the whole tectonic evolution process, there are three tectonic cycles from Changchengian period to Silurian for the QHJB [33]: the first tectonic cycle ends up with the first episode of Jinning movement $(\sim 1000 \mathrm{Ma})$, which is from the Changchengian period to the Jixianian period; the second tectonic cycle ends up with the second episode of Jinning movement ( $\sim 850 \mathrm{Ma})$, which is just during the Qingbaikou period; the third tectonic cycle ends up with the Caledonian movement, which is from the Sinian period to the Silurian period. At the end of the second tectonic cycle, when the Elder South China ocean is closed with 


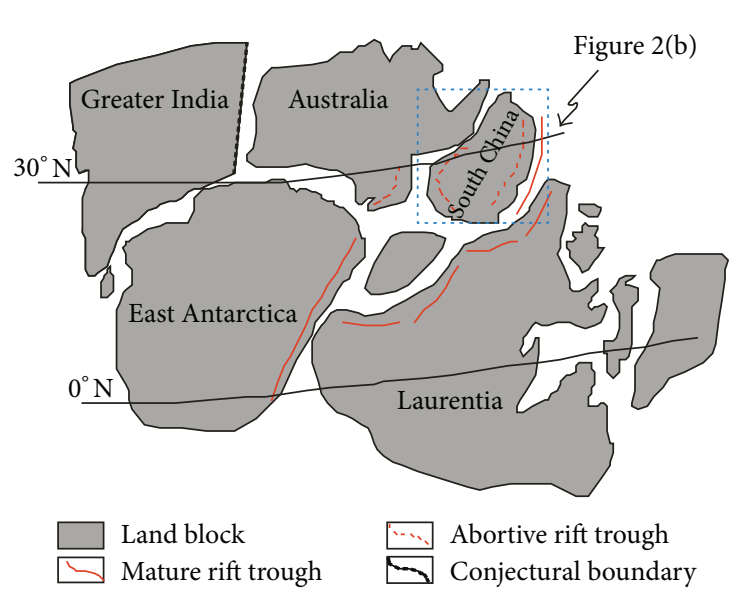

(a)

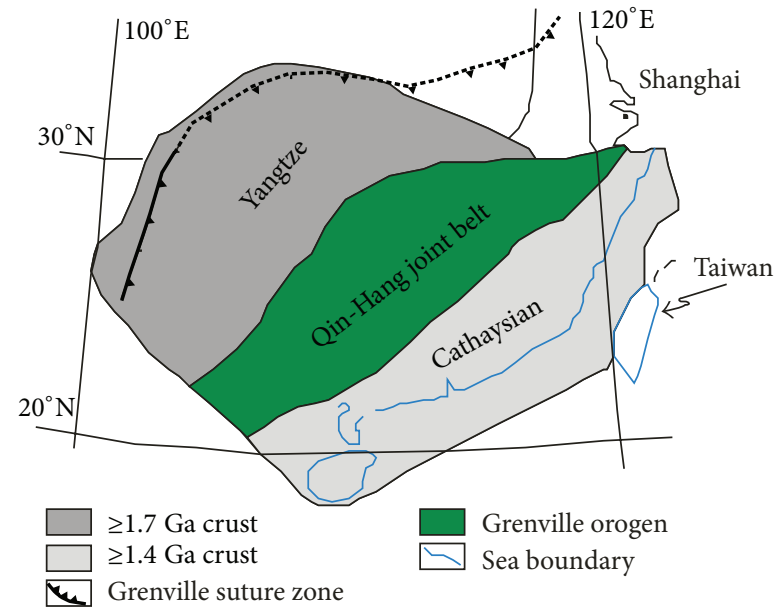

(b)

FIGURE 2: Early Neoproterozoic configuration of north Rodinia supercontinent (a) and South China block (b) ((a) after [54]; (b) after [57]).

collisional matching, the Yangtze and Cathaysian blocks are cohered together to form South China block which is a part of Rodinia supercontinent [55]. Affected by the fragmentation events of Rodinia supercontinent (Figure 2(a)), the South China block is splitted up into Yangtze and Cathaysian blocks again (Figure 2(b)). Additionally, the prevenient Cathaysian block is further splitted up into three slight blocks with rift troughs as insulation, and these small blocks are named South Zhejiang-North Fujian mountain, Middle JiangxiSouth Jiangxi mountain and Yunkai mountain [31]. There is a collisional matching for the Yangtze and Cathaysian plates during the Caledonian event, and the two plates are cohered to a unified South China block again which agrees with the formation of Gondwana supercontinent. As a part of the Gondwana supercontinent, the South China block is covered by the Neodevonian uniform sedimentary veneer entirely. There are several cycles of tension and compression after the Caledonian movement [34], when the whole South China plate is resplitted up again with the separation of Yangtze and Cathaysian plates. Between Yangtze and Cathaysian plates, there also exists the QHJB, whose tectonic property remains an uncertainty and will be discussed in this paper. In the published papers, the QHJB is an ocean basin due to the Neopaleozoic ophiolitic melange [28] and early Mesozoic acid volcanic rocks [35], but it is also treated to be an inland fault zone and rift [56] for the absence of ophiolitic and homochronous magmatic rocks since Sinian [31]. During the Hercynian and Indosinian, the tension ends up with compression contributed by the final Hercynian movement and Indosinian movement. The ultimate matching for the Yangtze and Cathaysian plates is due to the Dongwuian event in Permian [41], and the whole plate solidified as the result of the Yanshan movement [56].

2.2. Geological Characteristics of Dongxiang Area. The QHJB is divided into north, middle, and south segments due to the diversities in metallogenesis and geological evolution. In the previous studies, there are obvious differences in QHJB for its metallogenesis [37, 39], hydrothermal sedimentation [38], and geological evolution [36], which denote a subsection with latitude lines of $24^{\circ} \mathrm{N}$ and $27^{\circ} \mathrm{N}$ (Figure 3(a)). According to this, the QHJB is divided into north, middle, and south segments, and the middle segment of QHJB $\left(24-27^{\circ} \mathrm{N}\right)$ is in accordance with Nanling mountain chain. In north segment, there is a Dongxiang copper-polymetallic ore deposit which is located in the Xinjiang basin at the south margin of the Jiangnan terrane. The Xinjiang basin is a secondary fault basin, which is distributed across the west of the QiantangjiangXinjiang taphrogenic trough $[48,49]$. In the north segment of QHJB, there are two deep faults running in ENE direction, which are Qianshan-Pingxiang fault and Northeast JiangxiQianshan-Pingxiang fault. In addition, the Dongxiang ore district is distributed in the northeast of Northeast Jiangxi fault and is located in the northwest of Qianshan-Pingxiang fault.

The regional geology is simple relatively in the Dongxiang ore district. There are strata in three periods in the Dongxiang ore deposit, Fuzhou city, Jiangxi province, and South China (Figure 3(b)). The rocks in the late Cretaceous strata include purple sandstone and conglomerate. The Carboniferous strata are mainly composed of clastic rock with interlayered volcanic clastic. In the Proterozoic strata, there are pelitic, limestone, and microsandstones. The metamorphism is relatively slight, and these rocks only partially metamorphosed into phyllite. The magmatism is weak with dykes of granite porphyry, granodiorite porphyry, and rhyolite. The strata generally form a monocline, which changes slightly with an approximate occurrence of $145^{\circ} \angle 35^{\circ}$. Numerous fractures are distributed in the Dongxiang mining area, and their outcrops are on strikes of NE-ENE, SN, and NW directions. Additionally, the fractures along the NE-ENE strike represent a stripping fault, which are manifested as the main ore controlling fractures.

The Neopaleozoic siliceous rocks are collected from the mining area of Dongxiang area in the north segment of Qinzhou-Hangzhou joint belt. In the Xinjiang basin, there 


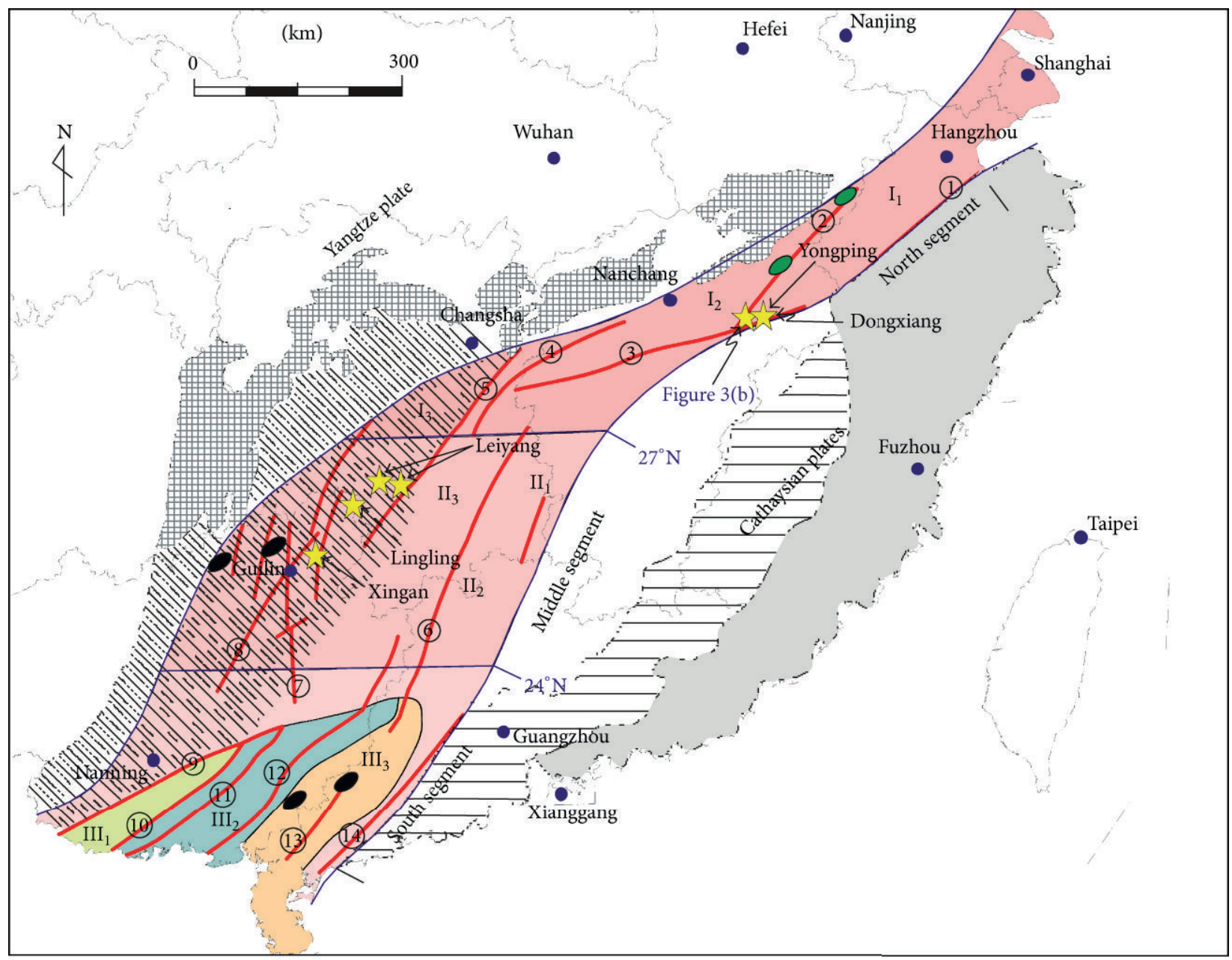

Fault zone:
(1) Jiangshan-Shaoxing;
(2) Northeast of Jiangxi province;
(3) Qianshan-Pingxiang;
(4) Liling-Wenjiashi;
(5) Changshoujie-Shuangpai;
(6) Chaling-Linwu-Huaiji;
(7) Longsheng-Yongfu;
(8) Guilin-Laibin;

Secondary tectonic units:

North segment:

$\mathrm{I}_{1}$ Jiangshan-Shaoxing ductile shear zone

$\mathrm{I}_{2}$ Northeast Jiangxi province faultzone

$\mathrm{I}_{3}$ Yanshan-Pingxiang fault zone

Middle segment:

$\mathrm{II}_{1}$ Xitian-Wanyangshan-Zhuguangshan

$\mathrm{II}_{2}$ Jiuyishan-Qitianling-Dadongshan-Jiufengshan

$\mathrm{II}_{3}$ Yangmingshan-Hengshan

Late Yanshanian volcanic rock

层 Indosinian-Yanshanian magmatic rock

冊曲 Jiangnan orogen

5.7. Littoral molasse

Neritic flysh

$\square$ Boundary of Qin-Hang joint belt
(9) Pingxiang-Dali;

(10) Hengxian;

(11) Lingshan-Tengxian;

(12) Bobai-Cenxi;

(13) Xinyi-Lianjiang;

(14) Wuchuan-Sihui.

South segment:

III $_{1}$ Shiwandashan basin

$\mathrm{III}_{2}$ Qin-Fang ocean trough

$\mathrm{III}_{3}$ Yunkaidashan uplift

(a)

FIgURE 3: Continued. 


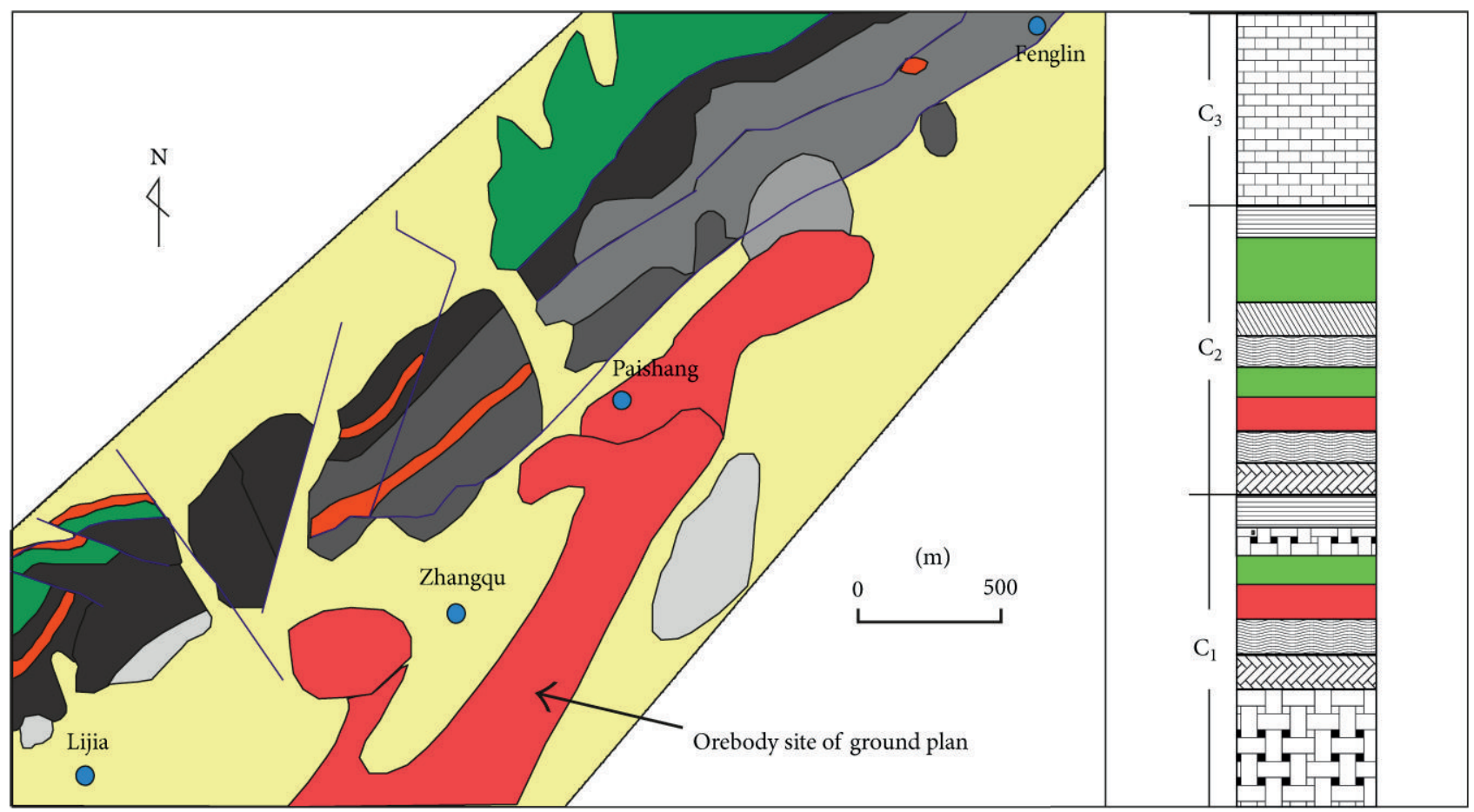

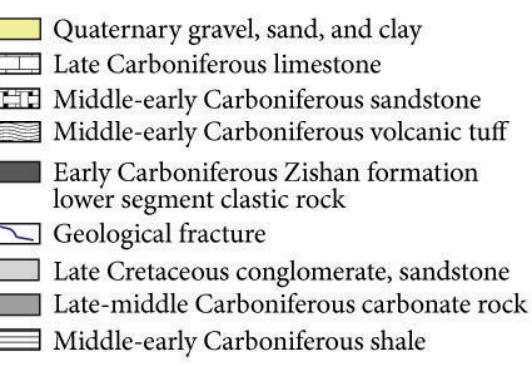

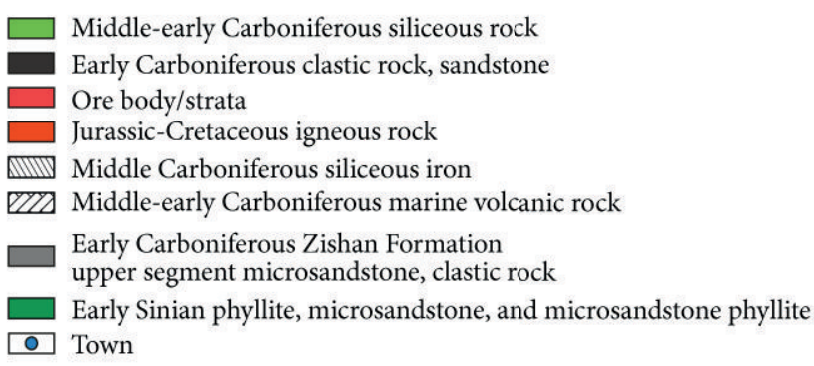

(b)

Figure 3: Geological map of QHJB (a) and Dongxiang area (b) ((a) after [36]; (b) after [48, 58]).

are several VMS-type polymetallic ore deposits including Dongxiang ore deposit, Yongping ore deposit, and Lehua ore deposit, and they exhibit intergrowth with siliceous rocks (Figure 3(b)). The siliceous rocks have outcropping conformably to the strata, which are either sill-like or conformable. The strata of siliceous rocks, with a thickness of up to 20 meters, are located in Carboniferous strata, which are located below the land surface about 100 meters to 150 meters. These siliceous rocks are often accompanied by carboniferous marine volcanic rock systems and massive sulphide-rich ore strata. In this paper, the siliceous rocks were collected from the mining area of Dongxiang copperpolymetallic ore deposit, Fuzhou city, Jiangxi province, South China, which is located in the north segment of Qinzhou-Hangzhou joint belt.

2.3. Petrological Characteristics. In the Dongxiang copper mining area, the sulfide ore (Figure 4(a)) and siliceous rocks (Figure 4(b)) were collected from the mine below the land surface. The ore were composed of volcanic breccia and metal sulphide minerals (Figure 4(a)), and the volcanic breccias were cemented by the metal sulphide minerals (e.g., pyrite, chalcopyrite, galena, and sphalerite). The galena and sphalerite were shown to be coarse-grained breccia (Figure 4(a)), while the minor chalcopyrites were scattered and coarsegrained. Additionally, the pyrites in small quantity were distributed in the fissures among volcanic breccias with vein shape. The siliceous rocks were grey and compact (Figure 4(b)) and consisted of authigenic quartz grains with low crystallinity microscopically (Figure $4(\mathrm{c})$ ). The finegrained or micrograined quartz grains were shown to be less automorphic and have closely-packed texture, which is in high agreement with the siliceous rocks originated from hydrothermal sedimentation $[45,59]$. Furthermore, slight recrystallization happened to the siliceous rocks with coarser grains, which were sometimes arranged in a line like a quartz vein (Figure 4(d)). 


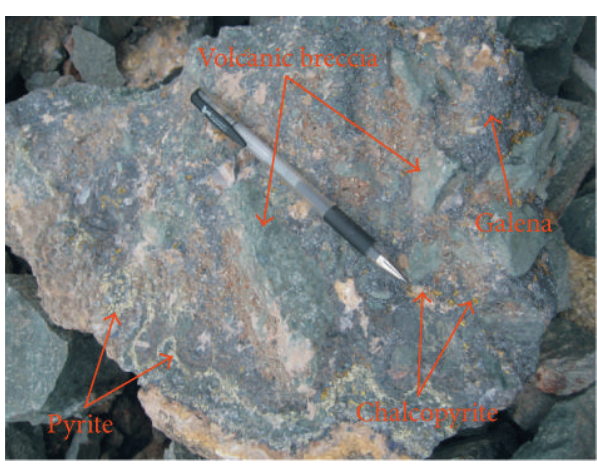

(a)

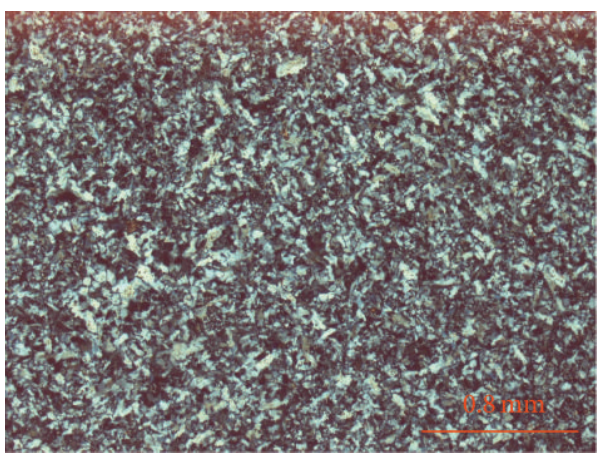

(c)

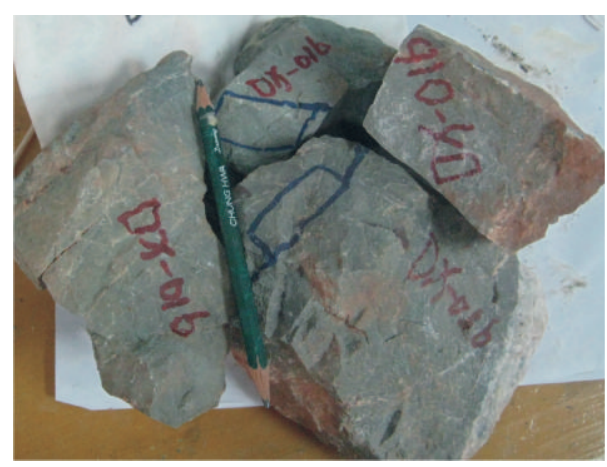

(b)

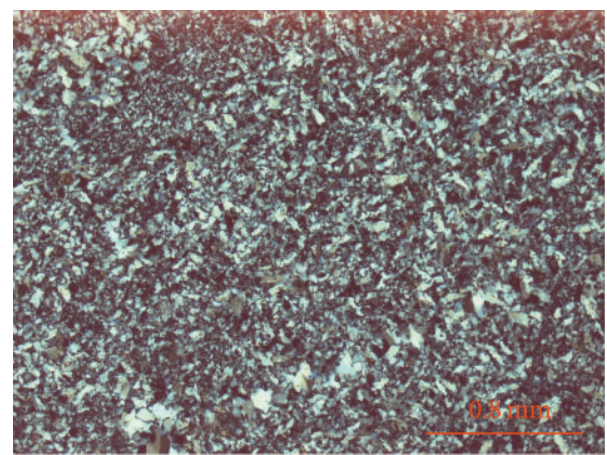

(d)

Figure 4: Siliceous rock from the Dongxiang ore deposits region ((a) ore including pyrite, galena, and chalcopyrite; (b) grey samples of siliceous rock; (c) fine-grained siliceous rock; (d) quartz-veined siliceous rock).

\section{Samples and Experiments}

In the pretreatment processes, fresh samples were selected, cleaned in ultrapure water, dried, and then divided into two groups. One group was polished into thin sections $(\leq 0.03 \mathrm{~mm})$, and the other group was broken into grains of $3 \mathrm{~mm}$ diameter, using cleaned corundum jaw breakers. Some of that sample was selected, cleaned, redried, and ground into grains with diameter of $0.075 \mathrm{~mm}$ in an agate ball mill (NO. XQN-500x4). Additionally, all the ore-hosted siliceous rocks were separated from the ore several times to purify them.

The pretreatment and analysis of the principal elements were carried out in the State Key Laboratory of Ore Deposit Geochemistry, Institute of Geochemistry, Chinese Academy of Sciences. In this study, the $\mathrm{SiO}_{2}$ content was analysed by classic gravimetric method. The $\mathrm{Al}_{2} \mathrm{O}_{3}$ content was analysed by EDTA titrimetric method (content $>1 \%$, accuracy of $1.5 \%$ ). The $\mathrm{TiO}_{2}$ and $\mathrm{P}_{2} \mathrm{O}_{5}$ contents were analysed by colorimetric method. The $\mathrm{K}_{2} \mathrm{O}, \mathrm{Na}_{2} \mathrm{O}, \mathrm{MnO}, \mathrm{CaO}$, and $\mathrm{MgO}$ contents were analysed by atomic absorption spectroscopy (instrument type PE-5100), to an accuracy of $0.2 \%$. The $\mathrm{FeO}$ and $\mathrm{Fe}_{2} \mathrm{O}_{3}$ contents were obtained by potassium dichromate titration method.

Inductively coupled plasma mass spectrometry (ICP-MS, instrument model: PE Elan 6000) was carried out in the State Key Laboratory of Geological Processes and Mineral Resources, China University of Geosciences. The analysis accuracy of the ICP-MS lay between $1 \%$ and $3 \%$ and was used to test the presence of trace and rare earth elements. The test was prepared from an acid-soluble solution in accordance with the standard process. Samples were weighed out to $100 \mathrm{mg}$ and then placed in the sealed Teflon cell before the addition of $1 \mathrm{~mL}$ concentrated $\mathrm{HF}$ and $0.3 \mathrm{~mL} 1: 1$ $\mathrm{HNO}_{3}$. After ultrasonic oscillation, samples were placed on a $150^{\circ} \mathrm{C}$ hot plate and then evaporated to dryness, rejoined with the same amount of $\mathrm{HF}$ and $\mathrm{HNO}_{3}$, and heated under confinement for a week (at about $100^{\circ} \mathrm{C}$ ). After evaporation and dissolution by $2 \mathrm{~mL}$ of $1: 1$ nitric acid, the sample was diluted 2000-fold and finally tested by PE Elan 6000 ICPMS. The results of trace element concentrations are shown in Tables 2 and 3, respectively.

The pre-treatment for the XRD analysis was performed in the Guangdong Provincial Key Laboratory of Geological Processes and Mineral Resource Survey. XRD analysis was carried out in the laboratory of the College of Chemistry and Chemical Engineering of Sun Yat-sen University. XRD data were collected with an X-ray powder diffractometer (instrument type: D/Max-2200 vpc) using the reflection focusing geometry ( $\mathrm{Cu} \mathrm{K} \alpha$ radiation; $40 \mathrm{kV}$ at $30 \mathrm{~mA}$; scanning speed: 0.12 s per step; step length: $0.02^{\circ}$; continuous scanning mode). Over the range of scanning angle from $5^{\circ}$ to $100^{\circ}$, the data were analysed by JADE-5.0 software with the eight highest peaks as the basis for their identification of each mineral type.

The EPMA analysis was carried out by the State Key Laboratory of Ore Deposit Geochemistry, Institute of Geochemistry, Chinese Academy of Sciences. The instrument 
type was a JEOL JSM-6460LV $(20 \mathrm{kV})$, and the X-ray EDS was produced by the EDAX company. The resolution of the instrument was $3.0 \mathrm{~nm}$ and the magnification is $5 \sim 300,000$.

\section{Characteristics of Distribution and Geochemistry}

4.1. Distribution Characteristics. In South China (Figure 3(a)), the QHJB was 2000 kilometres in length and 100 150 kilometres in width [31]. In this study, the distribution of siliceous rocks was calculated with the basic unit of county. When the siliceous rocks were distributed in the uniform place with diverse strata, these siliceous rocks would be separated with basic unit of formation. So, the siliceous rocks were calculated with formation and county as the temporal unit and spatial unit, respectively, whose distribution category included Zhejiang, Jiangxi, Hunan, Guangdong, and Guangxi provinces. What is more, Precambrian strata were divided into Mesoproterozoic and Neoproterozoic (Sinian) strata cursorily according to the literature [60-64]. Calculated from the regional geology of Zhejiang, Jiangxi, Hunan, Guangdong, and Guangxi provinces [60-64], the temporal and spatial distributions of siliceous rocks in QHJB were listed in Table 1.

4.1.1. Temporal Distribution. The siliceous rocks were easy to develop more widely in tensional setting and decreased due to the compression setting. In QHJB (Table 1), the marine siliceous rocks were distributed from Mesoproterozoic to Cretaceous, whose widest eras of distribution of siliceous rocks were Neoproterozoic, Carboniferous, and Permian. The Neoproterozoic siliceous rocks were in the largest scale, which was possibly contributed by the long geological history. There were two phases with siliceous rocks in larger scale (Figure 5), which were in Caledonian and Hercynian, respectively: the first period for siliceous rocks in large scale was from Neoproterozoic to Ordovician and ended up with scale decreasing abruptly due to the Caledonian movement in Silurian; the second period for siliceous rocks in large scale was from Devonian to Permian and ended up with a sudden reduce in scale due to the Hercynian movement in the end of Permian. Since Triassic, the scales of siliceous rocks persisted to diminish, which were possibly contributed by the regression of the whole of South China. In QHJB, the geological setting was tensional in the Caledonian and Hercynian [31,33], when the siliceous rocks had large scale with the widest distribution due to these geological settings (Figure 5). However, the Caledonian movement and Hercynian movement contributed to compressional setting [34, 41], when the siliceous rocks showed small scale with the widest distribution due to the compressional setting. According to this, the widest distributions of siliceous rocks agreed with the tensional setting, whereas the decreasing distributions of siliceous rocks contributed by the compressional setting due to the geological movement. So, the siliceous rocks were preferential to develop more widely in tensional setting in the $\mathrm{QHJB}$ and decreased due to the compressional setting.

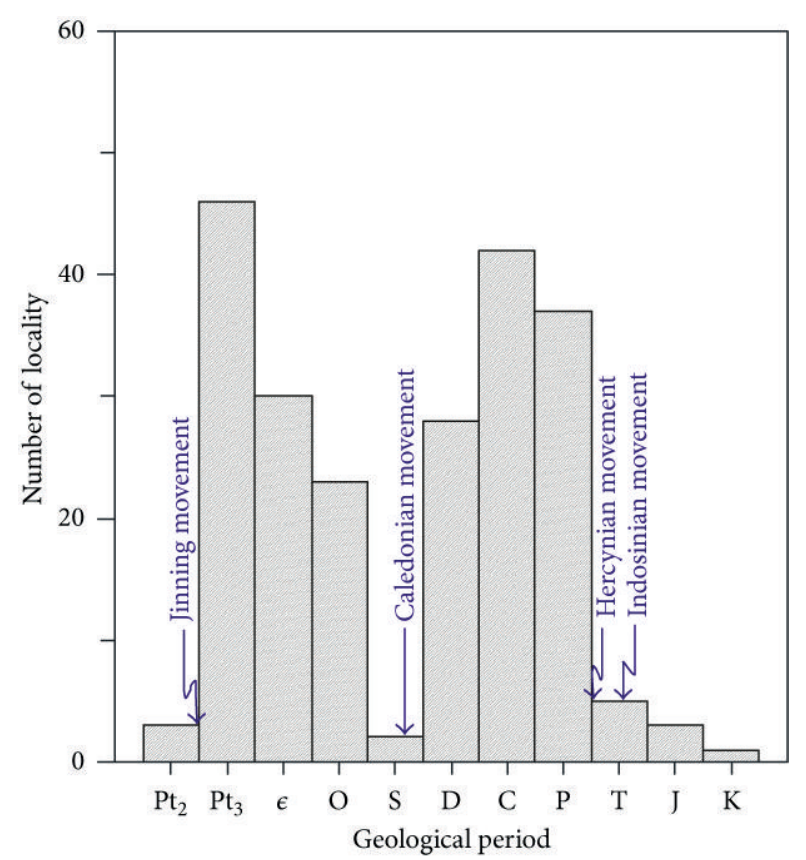

FIGURE 5: Column diagram of localities for siliceous rocks in QHJB (data were calculated from the literature [60-64]).

4.1.2. Spatial Distribution. The distribution of siliceous rocks acted as indication of the geological setting, and the tensional setting was propitious for the development of siliceous rocks. The siliceous rocks were widely distributed in Southeast China, whose majority were located in the category of inner and adjacency QHJB (Figures 6(a) and 6(b)). In the previous study, the QHJB was divided into north, middle $\left(24-27^{\circ}\right)$, and south segments [36]. According to this, the Caledonian siliceous rocks had majority in the north and middle segments, whereas the major siliceous rocks were located in middle and south segments in Hercynian. In the published paper, the breakup of South China started from the north segment possibly due to the mantle plume with transfer in southwest direction [55], and the collisional matching also began from north segment extending in southwest direction [33]. Based on the aforementioned, a tensional setting agreed with the siliceous rocks developing in a larger scale relatively, whereas the compressional setting was adverse to the development of siliceous rocks. According to this, the diversities in spatial distribution of siliceous rocks came from the hysteresis on geological setting, which came from the passing of geological setting from north segment to south segment. In the Caledonian, the tensional setting was too late to the evolution of siliceous rocks in the south segment, which meant a relatively shorter time for the sedimentation of siliceous rocks in the south segment than north and middle segments. In the Hercynian, the compressional setting was too early to prevent the evolution of siliceous rocks, which contributed to a long time for the development of siliceous rocks in the south segment than north and middle segments. In addition, the distribution of siliceous rocks acted as indication of the geological setting, 


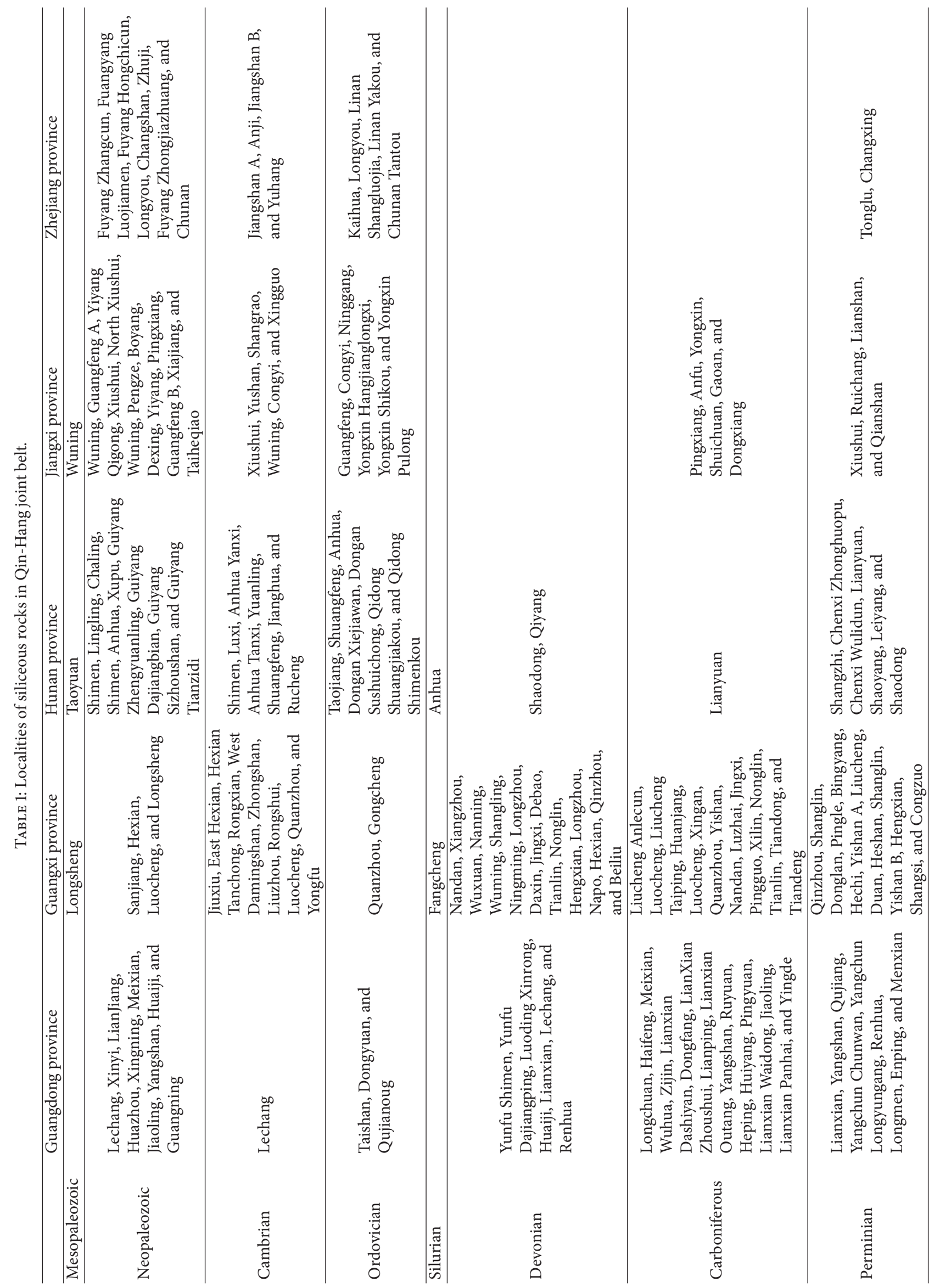




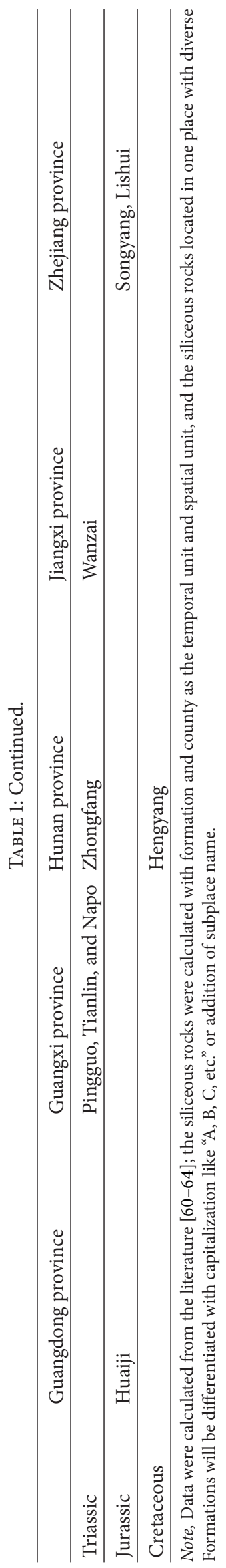


TABLE 2: Major element analysis data for siliceous rocks from Dongxiang area (\%).

\begin{tabular}{lccccccccccccc}
\hline No. & $\mathrm{SiO}_{2}$ & $\mathrm{TiO}_{2}$ & $\mathrm{Al}_{2} \mathrm{O}_{3}$ & $\mathrm{Fe}_{2} \mathrm{O}_{3}$ & $\mathrm{FeO}$ & $\mathrm{MnO}$ & $\mathrm{MgO}$ & $\mathrm{CaO}$ & $\mathrm{Na}_{2} \mathrm{O}$ & $\mathrm{K}_{2} \mathrm{O}$ & $\mathrm{P}_{2} \mathrm{O}_{5}$ & $\mathrm{LOI}$ & $\mathrm{Total}$ \\
\hline DX013a & 79.10 & 0.15 & 8.66 & 2.00 & 1.76 & 0.11 & 2.50 & 0.50 & 1.30 & 1.87 & 0.07 & 1.79 & 99.81 \\
DX013b & 80.35 & 0.17 & 8.54 & 2.20 & 1.75 & 0.12 & 1.42 & 0.53 & 1.32 & 1.65 & 0.08 & 1.65 & 99.78 \\
DX015 & 79.49 & 0.20 & 9.71 & 1.30 & 1.56 & 0.05 & 0.75 & 0.39 & 3.00 & 1.89 & 0.07 & 1.35 & 99.76 \\
DX016 & 77.13 & 0.22 & 10.12 & 2.20 & 2.06 & 0.10 & 1.15 & 0.58 & 3.52 & 0.82 & 0.08 & 2.06 & 100.04 \\
DX020 & 79.44 & 0.19 & 9.30 & 2.23 & 1.70 & 0.10 & 1.72 & 0.53 & 0.93 & 1.66 & 0.09 & 1.94 & 99.82 \\
DX024 & 79.67 & 0.20 & 8.93 & 1.41 & 2.15 & 0.09 & 0.73 & 0.51 & 1.10 & 2.78 & 0.08 & 2.46 & 100.11 \\
DX025 & 79.48 & 0.13 & 5.56 & 1.33 & 2.10 & 0.32 & 1.27 & 2.48 & 0.65 & 1.25 & 0.07 & 5.16 & 99.80 \\
DX026 & 82.84 & 0.11 & 5.20 & 2.20 & 1.58 & 0.27 & 0.76 & 1.27 & 0.49 & 0.48 & 0.07 & 4.60 & 99.87 \\
DX027 & 78.82 & 0.23 & 13.26 & 1.55 & 0.52 & 0.01 & 0.51 & 0.38 & 0.66 & 1.54 & 0.07 & 2.19 & 99.73 \\
DX028 & 87.80 & 0.10 & 5.65 & 1.48 & 0.46 & 0.12 & 0.60 & 0.54 & 0.71 & 1.04 & 0.07 & 1.27 & 99.84 \\
\hline Aver. & 80.41 & 0.17 & 8.49 & 1.79 & 1.56 & 0.13 & 1.14 & 0.77 & 1.37 & 1.50 & 0.07 & 2.45 & 99.86 \\
\hline
\end{tabular}

which meant the tensional setting had favorableness to the development of siliceous rocks.

4.2. Geochemical Characteristics. There were geochemical indicators of major and trace elements for siliceous rocks to identify their genesis, sedimentary environments, and geological setting. In the north segment of QHJB, the geochemical composition of the siliceous rocks in Dongxiang ore area was listed in Tables 2-4, which denoted the genesis and sedimentary environments as follows.

(1) The major elements of the siliceous rock from Dongxiang ore area were shown in Table 2, and they indicated the following information.

(a) The siliceous rocks were originated from hydrothermal sedimentation. The siliceous rocks had $\mathrm{SiO}_{2}$ ranged from $77.13 \%$ to $87.80 \%$ with an average of $80.41 \%$. The $\mathrm{Si} / \mathrm{Al}$ ratios lay between 5.24 and 14.04 with average of 9.13 , which were lower than those of pure siliceous rock (80 to 1400) [67]. The $\mathrm{Al} /(\mathrm{Al}+\mathrm{Fe}+\mathrm{Mn})$ values lay between 0.48 and 0.82 (average $=$ $0.63)$, which were higher than those of typical hydrothermal siliceous rocks with $\mathrm{Al} /(\mathrm{Fe}+\mathrm{Al}+\mathrm{Mn})<0.4$ [68]. The $\mathrm{MgO}$ content ranged from $0.60 \%$ to $2.50 \%$ (average $=1.14 \%$ ), which were higher than those of pure hydrothermal siliceous rocks [69]. The $\mathrm{Fe} / \mathrm{Ti}$ ratios ranged from 10.79 to 41.95 (average $=25.70$ ) and were basically consistent with those of typical hydrothermal sedimentary siliceous rocks with $\mathrm{Fe} / \mathrm{Ti}>20$ [70]. The $(\mathrm{Fe}+\mathrm{Mn}) / \mathrm{Ti}$ values ranged from 10.83 to 45.12 (average $=26.89$ ), which were consistent with those of typical hydrothermal siliceous rock with $(\mathrm{Fe}+\mathrm{Mn}) / \mathrm{Ti}>$ $20 \pm 5$ [70]. The $\mathrm{Fe}_{2} \mathrm{O}_{3} / \mathrm{FeO}$ ratios ranged from 0.63 to 3.22 (average $=1.45$ ), which were similar to those of typical hydrothermal siliceous rock being 0.51 [71]. As a whole, the geochemical characteristics above generally matched those of hydrothermal siliceous rocks and corresponded to the associated geochemical discrimination diagrams (Figures $7(\mathrm{a}), 7(\mathrm{~b})$, and $7(\mathrm{c}))$. Additionally, some of the geochemical indicators, such as the $\mathrm{Al} /(\mathrm{Al}+\mathrm{Fe}+\mathrm{Mn})$ values and the $\mathrm{MgO}$ contents, deviated slightly from those values exhibited by classic hydrothermal material, which possibly indicated the influence of terrigenous input or biological activities (Figure $7(\mathrm{c})$ ). So, the siliceous rocks were originated from hydrothermal sedimentation and were possibly influenced by terrigenous input or biological activities.

(b) The siliceous rocks deposited in a basin of the marginal sea. The $\mathrm{Al} /(\mathrm{Al}+\mathrm{Fe}+\mathrm{Mn})$ values ranged from 0.48 to 0.82 (average $=0.63$ ), which indicated the siliceous rocks of the marginal sea [42]. The $\mathrm{MnO} / \mathrm{TiO}_{2}$ ratios ranged from 0.03 to 2.46 (average $=0.92$ ), which were approximately consistent with those of siliceous rocks formed in the marginal sea [74]. The $\mathrm{Al} /(\mathrm{Al}+\mathrm{Fe})$ values lay between 0.50 and 0.82 (average $=0.64$ ), which were consistent with those of bedded siliceous rocks in the marginal seas [69]. The $\mathrm{Al}_{2} \mathrm{O}_{3} /\left(\mathrm{Al}_{2} \mathrm{O}_{3}+\right.$ $\mathrm{Fe}_{2} \mathrm{O}_{3}$ ) values ranged from 0.70 to 0.90 (average $=0.82$ ), which were consistent with those of typical siliceous rock with $\mathrm{Al}_{2} \mathrm{O}_{3} /\left(\mathrm{Al}_{2} \mathrm{O}_{3}+\mathrm{Fe}_{2} \mathrm{O}_{3}\right)>0.7$ from the continental margins [73]. So, these geochemical characteristics denoted the siliceous rocks deposited in the marginal sea, which was strongly supported by the associated geochemical discrimination diagrams (Figures $8(\mathrm{a})$ and $8(\mathrm{~b})$ ).

(c) The siliceous rocks had close relationship with volcanic activity. The $\mathrm{K}_{2} \mathrm{O} / \mathrm{Na}_{2} \mathrm{O}$ ratios ranged from 0.23 to 2.53 (average $=1.46$ ), and the samples with $\mathrm{K}_{2} \mathrm{O} / \mathrm{Na}_{2} \mathrm{O}<1$ agreed with those of the typical siliceous rocks related to submarine volcanism [69]. The $\mathrm{SiO}_{2} /\left(\mathrm{K}_{2} \mathrm{O}+\mathrm{Na}_{2} \mathrm{O}\right)$ values ranged from 16.26 to 85.40 (average $=35.05$ ), which were approximately consistent with those of siliceous rock arising from chemical sedimentation related to volcanic eruptions [75]. The $\mathrm{SiO}_{2} / \mathrm{Al}_{2} \mathrm{O}_{3}$ ratios ranged from 5.94 to 15.93 (average $=10.35)$, which approximately corresponded to those of siliceous rock originated from magmatism with $\mathrm{SiO}_{2} / \mathrm{Al}_{2} \mathrm{O}_{3}<13.7$ [76]. The $\mathrm{SiO}_{2} / \mathrm{MgO}$ ratios ranged from 31.64 to 154.55 (average $=88.91$ ), which were slightly higher than that of typical siliceous rocks related to magmatism with $\mathrm{SiO}_{2} / \mathrm{MgO}<69.5$ [76]. The $\mathrm{Al}_{2} \mathrm{O}_{3} / \mathrm{TiO}_{2}$ ratios ranged from 42.77 to 57.73 (average $=50.03$ ), which were consistent with those of siliceous rock with source area of magmatic rock [44]. In conclusion, the siliceous rock was shown to have genesis related to magmatism, which was strongly supported by the geochemical discrimination diagrams (Figures 9(a) and 9(b)). Additionally, there were slight biological contributions in the siliceous rocks (Figure 9(a)). So, the sedimentation for the siliceous rocks was affected by the volcanic eruption. 


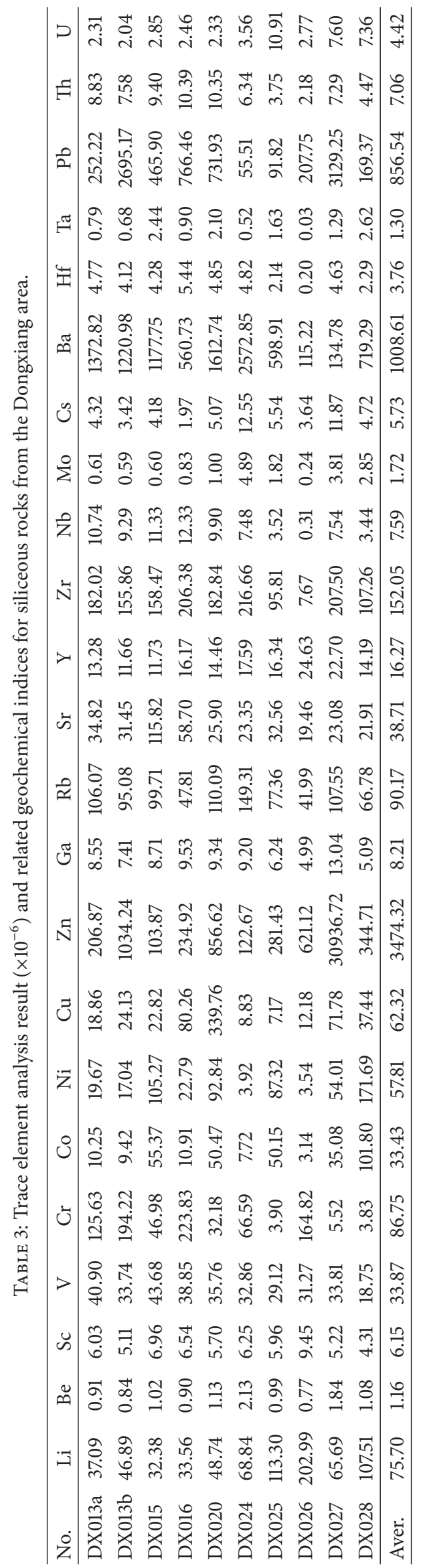




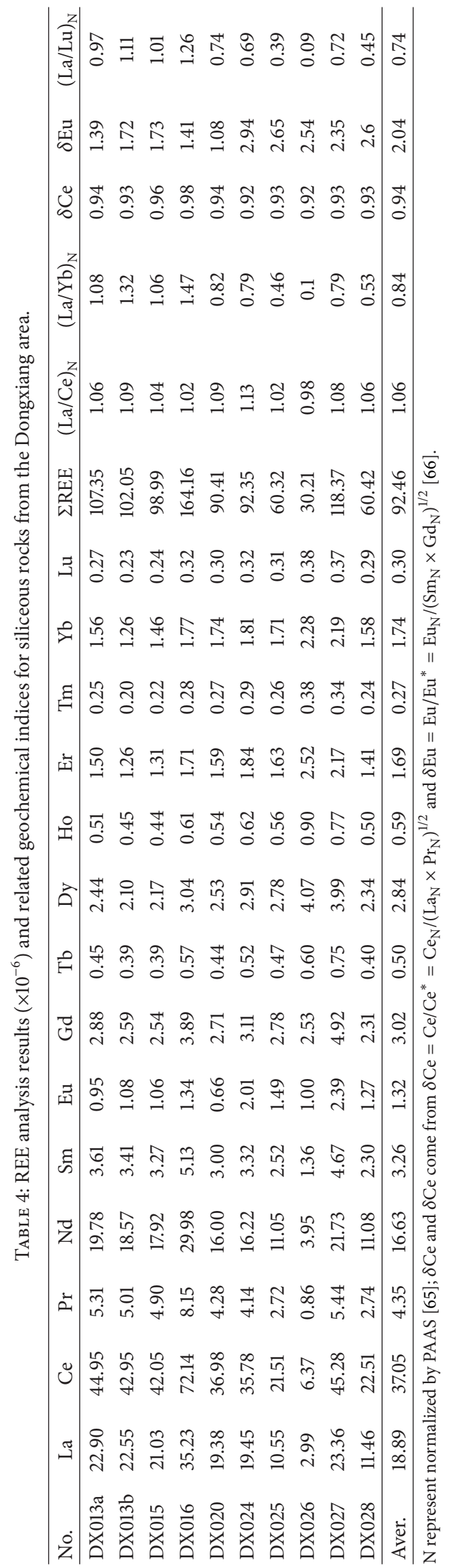




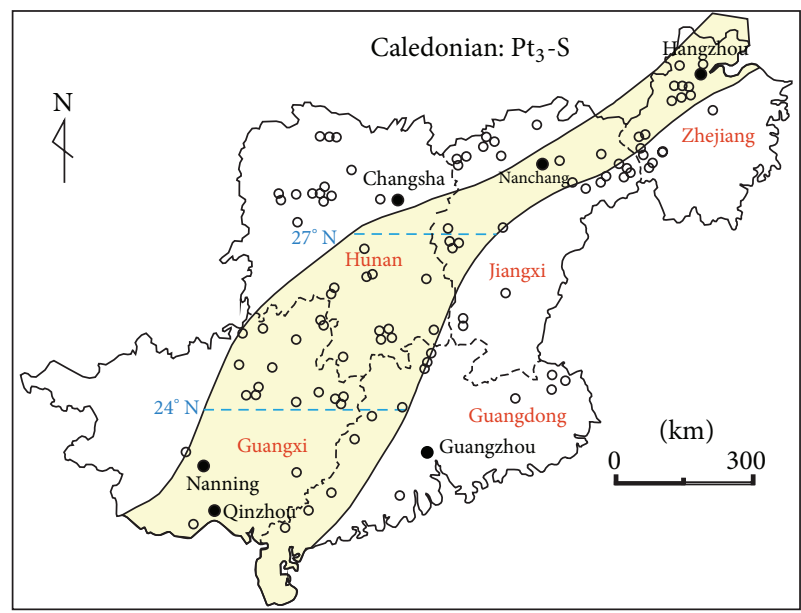

Qin-Hang joint belt

Boundary of Qin-Hang joint belt

Division of three segments

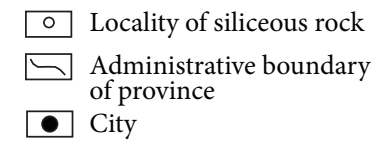

(a)

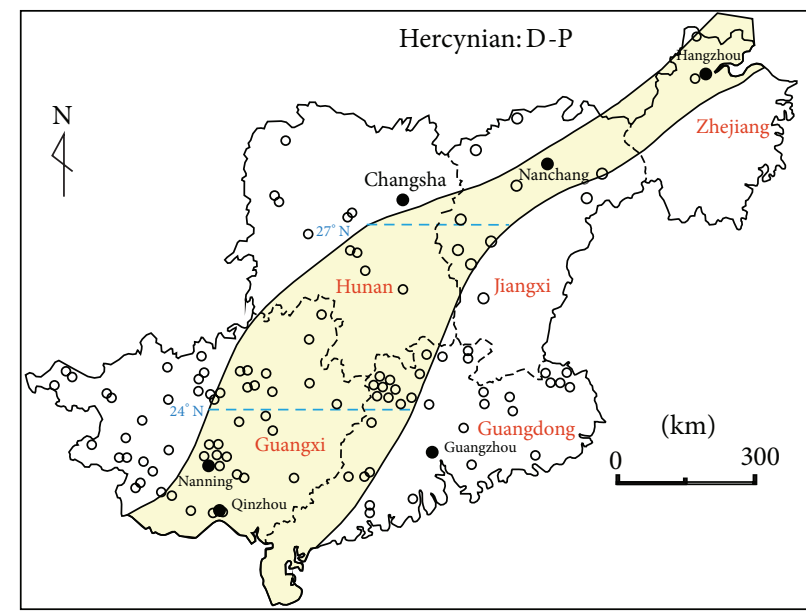

Qin-Hang joint belt Boundary of Qin-Hang joint belt

Division of three segments
Locality of siliceous rock of province City Administrative boundary

(b)

Figure 6: Distribution of siliceous rocks in large scale in Southeast China ((a) Caledonian period; (b) Hercynian period).

(2) The trace elements of the siliceous rock from Dongxiang ore area were presented in Table 3 , and they mainly indicated the following information.

(a) The siliceous rocks were hydrothermal genesis with possible terrigenous influences. The $\mathrm{Ba}$ content ranged from $115.22 \times 10^{-6}$ to $2572.85 \times 10^{-6}$ (average $=1008.61 \times 10^{-6}$ ), which was higher than that of typical crustal rocks with average Ba content of $707 \times 10^{-6}$ [77]. The $\mathrm{U}$ content ranged from $2.04 \times 10^{-6}$ to $10.91 \times 10^{-6}$ (average $=4.42 \times 10^{-6}$ ), and was higher than that of typical crustal rocks with average $U$ content of $1.30 \times 10^{-6}$ [77]. These geochemical characteristics agreed with those found in typical hydrothermal sedimentary siliceous rocks [78]. The $\mathrm{Ba} / \mathrm{Sr}$ ratios ranged from 5.84 to 110.17 (average $=33.34$ ), which agreed with hydrothermal siliceous rocks with $\mathrm{Ba} / \mathrm{Sr}>1[79]$. The $\mathrm{V} /(\mathrm{V}+\mathrm{Ni})$ values ranged from 0.10 to 0.90 (average $=0.51$ ), which denoted a reductive environment with $\mathrm{V} /(\mathrm{V}+\mathrm{Ni})>0.46[80]$. However, the $\mathrm{U} /$ Th ratios ranged from 0.22 to 2.91 (average $=0.87$ ), which were slightly lower than those of typical hydrothermal sediments [44]. According to this, the siliceous rocks were shown to be hydrothermal genesis, and this was supported by the plotting in $\mathrm{Mn}-10 \times(\mathrm{Cu}+\mathrm{Co}+\mathrm{Ni})$-Fe discrimination diagram (Figure 10). In addition, the samples deviated from the typical hydrothermal sediments (Figure 10), which possibly indicated the effect of terrigenous materials or volcanic input. So, the siliceous rocks were originated from hydrothermal sedimentation, which were possibly affected by the terrigenous materials or the volcanic input to some extent.

(b) The siliceous rocks deposited in a basin of marginal sea. The siliceous rocks have $\mathrm{Sc} / \mathrm{Th}$ ratios ranging from 0.55 to 4.33 (average $=1.19$ ), which were consistent with those of siliceous rocks of marginal seas $(\mathrm{Sc} / \mathrm{Th}>1)$ [44]. The U/Th ratios ranged from 0.22 to 2.91 with an average of 0.87 , and some of them were higher than those of siliceous rock of marginal seas [44]. The Sr/Ba ratios ranged from 0.02 to 0.17 (average $=0.07$ ), which agreed with those of siliceous rocks formed in the basin of a deep ocean or a shallow ocean in retention with $\mathrm{Sr} / \mathrm{Ba}<1$ [82]. According to $\mathrm{V} /(\mathrm{V}+\mathrm{Ni})$ values averaged 0.51 , the sedimentary basin was oxygen deficient, which denoted the $\mathrm{Sr} / \mathrm{Ba}$ ratios should indicate siliceous rocks of a deep ocean basin. Additionally, the siliceous rocks plotted in Ti-V discrimination diagram (Figure 11(a)) indicated the depositional ocean basin circumstance and tended to be nearer to the basin of a marginal sea in the $\mathrm{Ti} / \mathrm{V}-\mathrm{V} / \mathrm{Y}$ discrimination diagram (Figure 11(b)). This meant the siliceous rocks deposited in an ocean basin which was relatively far away from the continent itself. So, the siliceous rock should have been formed in a limited ocean basin in its width, which had also been proposed by the literature [83]. In conclusion, the siliceous rocks were formed in an ocean basin with limited width.

(3) The rare earth elements of the siliceous rock from Dongxiang ore area were shown in Table 4 and could indicate the following information.

(a) The siliceous rocks were originated from hydrothermal sedimentation, and the sedimentary system was possibly affected by terrigenous input. The $\Sigma$ REE values ranged from $30.21 \times 10^{-6}$ to $164.16 \times 10^{-6}$ (average $=92.46 \times 10^{-6}$ ), which agreed with those of typical hydrothermal sedimentary siliceous rocks with $\Sigma$ REE $<200 \times 10^{-6}$ [85]. Normalized by the PAAS [65], the $(\mathrm{La} / \mathrm{Yb})_{\mathrm{N}}$ values ranged from 0.10 to 1.47 (average $=0.84$ ), and this was consistent with those of typical hydrothermal sedimentary siliceous rock with $(\mathrm{La} / \mathrm{Yb})_{\mathrm{N}}<1$ [43]. Additionally, some samples with relatively higher $(\mathrm{La} / \mathrm{Yb})_{\mathrm{N}}$ values possibly indicated terrigenous input during the hydrothermal sedimentation, which was possibly 


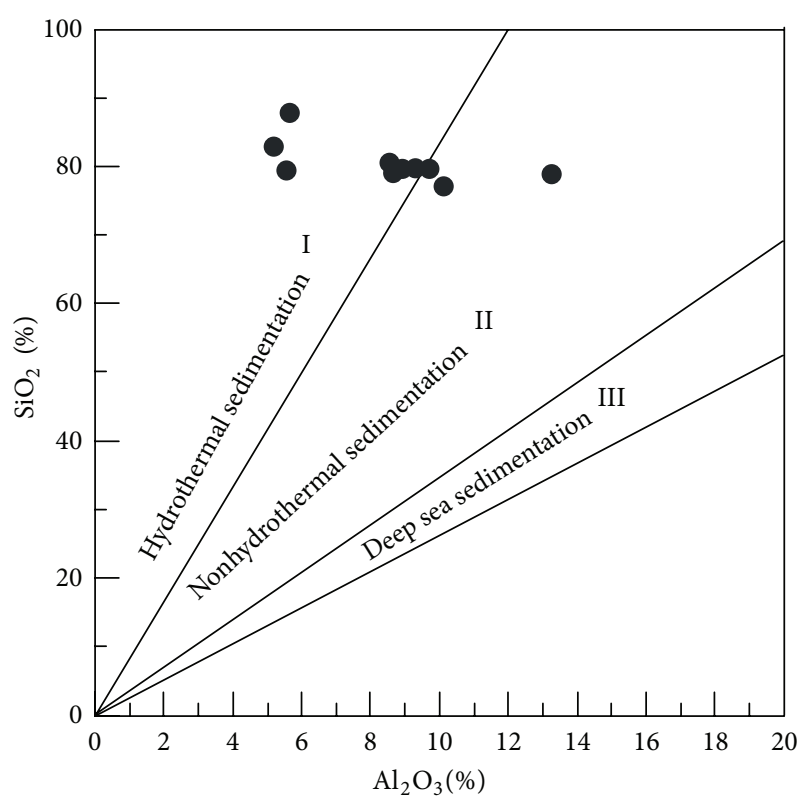

(a)

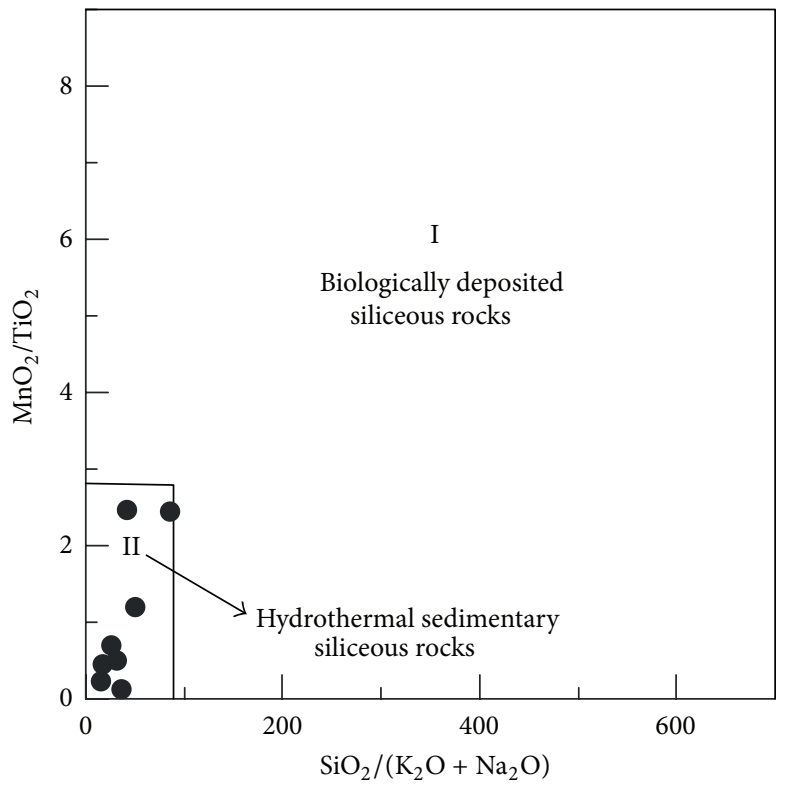

(b)

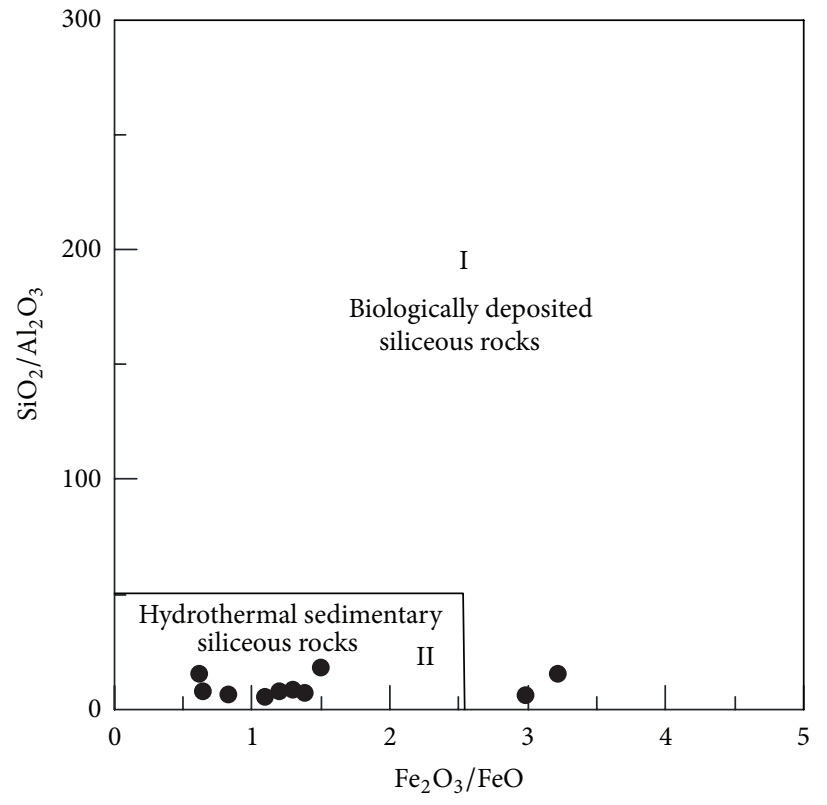

(c)

Figure 7: Major element discrimination diagrams for siliceous rocks of Dongxiang area ((a) after [72]; (b) after [73]).

contributed by the continent of magmatic differentiation or crustal contamination [86]. Normalized by PAAS (Figure 12(a)), the REE patterns were shown to be rich in HREE, left-leaning, positive Eu anomaly, and slightly negative $\mathrm{Ce}$ anomaly, which agreed with those of hydrothermal sedimentary siliceous rocks. Besides, there were also REE patterns deviated from those of typical hydrothermal sedimentary siliceous rocks partially (Figure 12(b)), which possibly reflected that the sedimentation system had been affected by nonhydrothermal material or volcanic activity. One of them was weakly right-leaning with an obvious positive $\mathrm{Eu}$ anomaly, while the other was left-leaning with a weak positive $\mathrm{Eu}$ anomaly. So, the hydrothermal sedimentation acted as the predominant mechanism for these siliceous rocks, and the hydrothermal sedimentation process was also affected by terrigenous materials or volcanic inputs.

(b) The siliceous rocks deposited in a width-limited ocean basin of a marginal sea. The $\Sigma$ REE values had an average of $92.46 \times 10^{-6}$, which was close to that of siliceous rock formed in the marginal sea [43]. Normalized by the PAAS [65], the $(\mathrm{La} / \mathrm{Yb})_{\mathrm{N}}$ values ranged from 0.10 to 1.47 (average $=0.84$ ), which matched those of siliceous rocks formed both in 


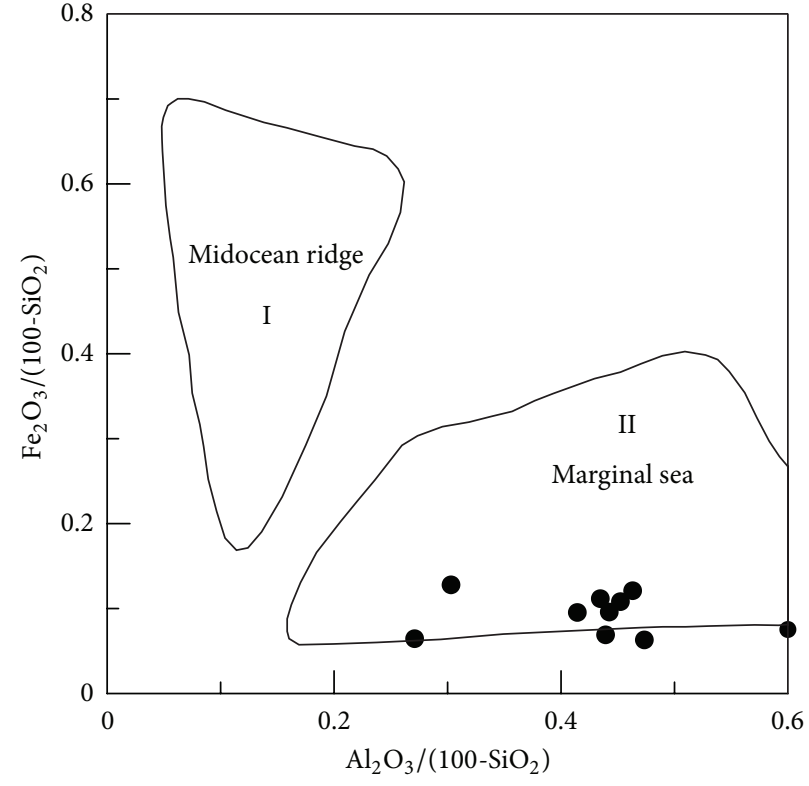

(a)

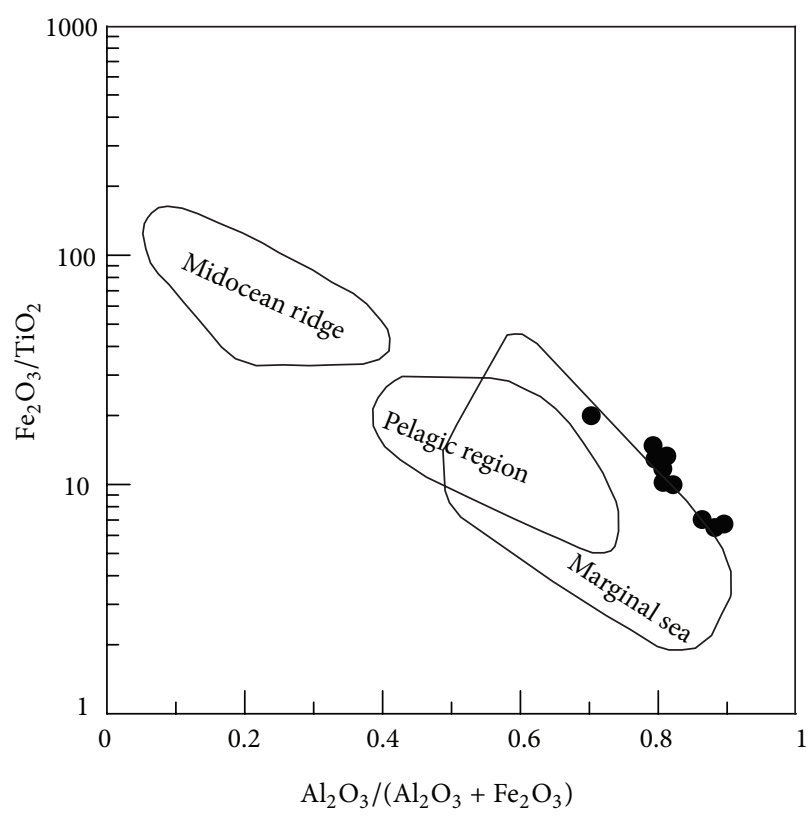

(b)

FIGURE 8: Major element discrimination diagrams for siliceous rocks of Dongxiang area (after [73]).

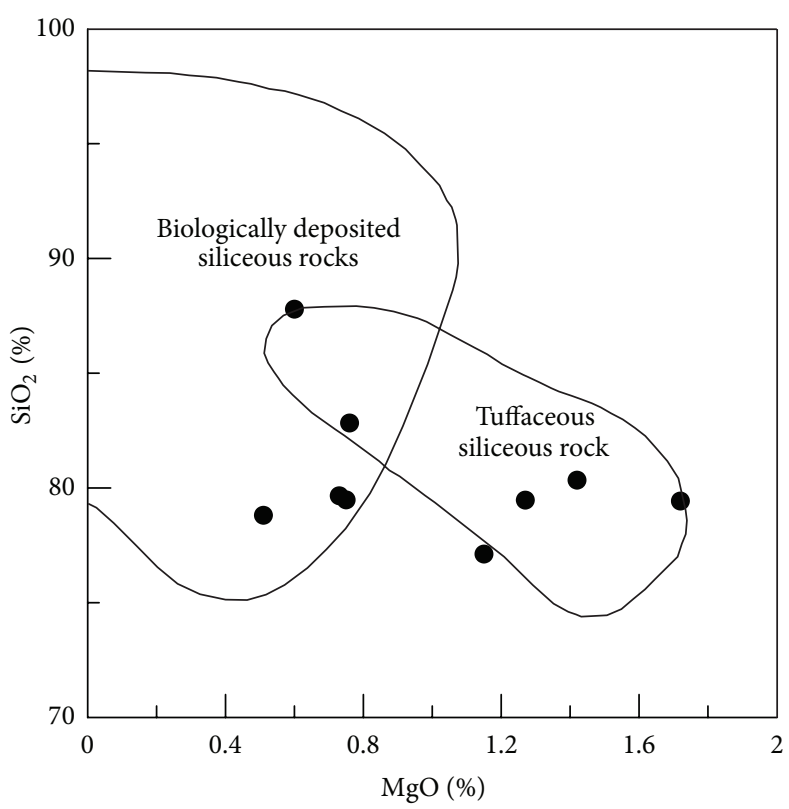

(a)

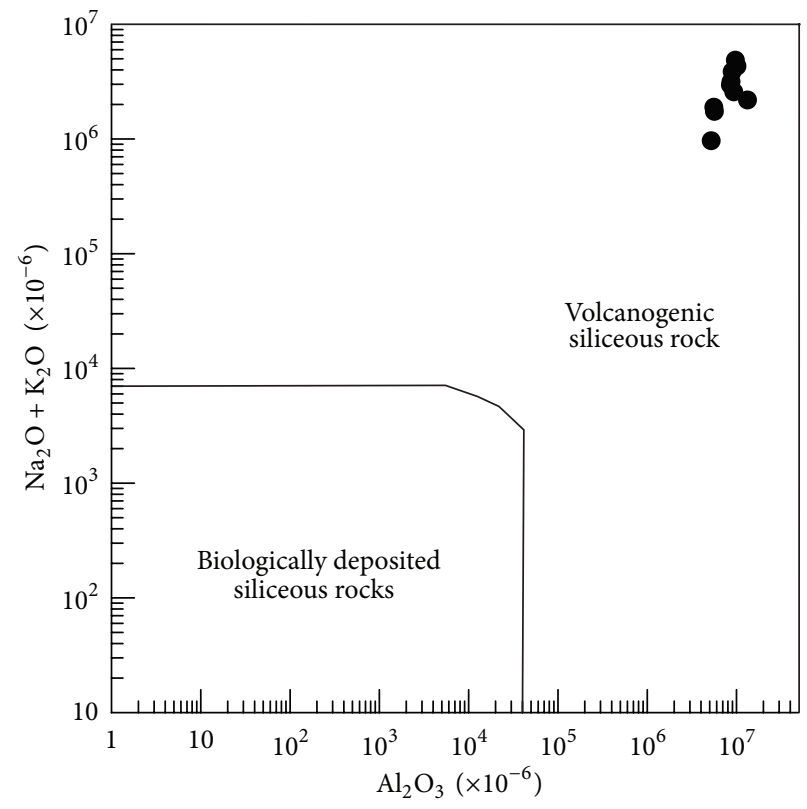

(b)

FIGURE 9: Major element discrimination diagram of siliceous rocks of Dongxiang area (after [73]).

marginal sea or ocean basins [43]. The $\delta$ Ce value ranged from 0.92 to 0.98 (average $=0.94$ ), which was consistent with siliceous rock of marginal sea with $\delta$ Ce from 0.83 to 1.33 [85]. The $(\mathrm{La} / \mathrm{Ce})_{\mathrm{N}}$ values ranged from 0.98 to 1.09 (average $\left.=1.06\right)$, which agreed with those of siliceous rock from a marginal sea [73]. The $\delta$ Eu values ranged from 1.08 to 2.65 (average $=2.04$ ), which were much higher than those of siliceous rock from the MOR with $\delta$ Eu being 1.35 [85]. The $(\mathrm{La} / \mathrm{Lu})_{\mathrm{N}}$ values ranged from 0.09 to 1.26 (average $=0.74$ ), which were consistent with those of siliceous rock from marginal sea with $(\mathrm{La} / \mathrm{Lu})_{\mathrm{N}}$ values being 0.79 [85]. The siliceous rocks had obvious negative $\mathrm{Ce}$ anomaly in the middle ocean ridge $[43,87]$, which was not apparent in the littoral siliceous rocks. Therefore, the weak negative Ce anomaly in the siliceous rocks denoted that they were possibly formed at the basin of a marginal sea (Figure 12(a)), which was strongly supported 


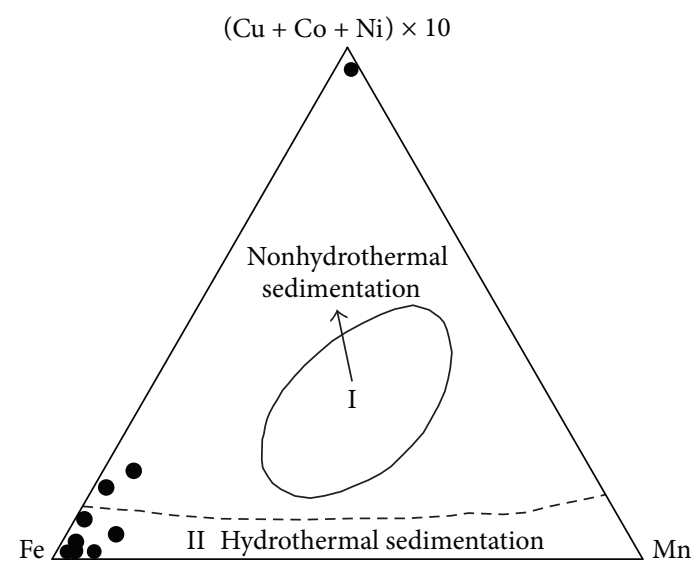

FIGURE 10: Major element discrimination diagram of siliceous rocks in Dongxiang area (after [81]).

by the $\mathrm{Al}_{2} \mathrm{O}_{3} /\left(\mathrm{Al}_{2} \mathrm{O}_{3}+\mathrm{Fe}_{2} \mathrm{O}_{3}\right)-(\mathrm{La} / \mathrm{Ce})_{\mathrm{N}}$ diagram (Figure 13). So, the siliceous rock deposited in an ocean basin of a marginal sea.

4.3. XRD Analysis. The $\alpha$-quartz were shown to be the major mineral in the X-ray powder diffraction result (Figure 14(a)), which had two kinds of cell parameters (Figure 14(b)). There were trace impurities, such as minerals of carbonate and clay, which were concealed due to their lower concentrations. The first kind of $\alpha$-quartz (Qtz) was hexagonal with space group P3121(152), whose crystal cell parameters were $a=$ $b=4.913 \AA, c=5.405 \AA$, and $Z=3$. The second kind of $\alpha$-quartz (Qtzl) was rhombohedral with space group P3221(154), whose crystal cell parameters were $a=b=$ $4.914 \AA, c=5.406 \AA$, and $Z=3$. In comparison with standard minerals, the first kind of quartz belonged to standard $\alpha$-quartz with cell parameters $a=b=4.913 \AA, c=5.405 \AA$, and $Z=3$, while the crystal cell parameters of the other $\alpha$ quartz (Qtzl) were a little longer than those of the standard $\alpha$-quartz.

The $\alpha$-quartz with lengthening cell parameter was possibly originated from the isomorphous substitution of impurity elements. The crystal cell parameters were similar if they were formed in identical evolution processes with similar circumstances. According to the literature [88, 89], changes in the crystal cell parameters can be contributed by temperature [90], stress [91], transformation into different crystal forms [92], and isomorphous substitution [93]. However, only the isomorphous substitution could lengthen the cell parameter, which would be the most possible mechanism for the $\alpha$ quartz (Qtzl) with lengthening cell parameters. So, the lengthening cell parameters of $\alpha$-quartz possibly came from the isomorphous substitution of impurity elements.

4.4. Microarea Analysis. The siliceous rocks were originated from hydrothermal sedimentation. In the EBSD images, the brightness is in positive correlation with the proton number of those elements comprising the minerals [88, $89,94]$. According to this, the low proton number in the $\mathrm{SiO}_{2}$ minerals implied low brightness and dark colour, while the clay minerals and metal sulphides had higher brightness with a whiter colour because of their larger proton numbers. In this study, the siliceous rock was mainly composed of silica mineral (Figures 15(a) and 15(b)), a scattering of felsic minerals (Figures 15(a) and 15(c)), and metal sulphides (such as pyrite) (Figures 15(a) and 15(d)). Additionally, the carbon element in the EDS analysis data is brought during the sample production process. The silica mineral (quartz) was low in crystallinity, less automorphic, and fine-grained with typically close-packed texture (Figure 15(a)). This phenomenon matched the hydrothermal sedimentary siliceous rocks which precipitated from the hydrothermal water and crystallised rapidly. Furthermore, there were straight boundaries for the pyrite with scattered distribution (Figures 15(a) and 15(c)), which contributed to evidence of sedimentary genesis as well as the siliceous rocks.

\section{Discussion}

5.1. Provenance and Genesis. Siliceous rocks in the Dongxiang area originated from hydrothermal sedimentation, as is strongly supported by both microfabric and geochemical characteristics. The authigenic quartz of the siliceous rocks displays low crystallinity and less automorphism with a closepacked texture (Figures 4(c), 4(d), 15(a), and 15(b)). The thimbleful impurity minerals have a scattered distribution, which originated from syndeposition (Figures 15(a), 15(c), and $15(\mathrm{~d}))$. These microfabric characteristics agree with a hydrothermal genesis, and they also indicate that the primary precipitation rate of silica was too high to crystallise. The siliceous $\mathrm{SiO}_{2}$ content ranges from $77.13 \%$ to $87.80 \%$ (average $=80.41 \%$, which is in agreement with hydrothermal genesis. In addition, their $\mathrm{Ba}$ averaged $1008.61 \times 10^{-6}, \mathrm{U}$ averaged $4.42 \times 10^{-6}$, and $\Sigma \mathrm{REE}$ values averaged $92.46 \times 10^{-6}$. The siliceous rocks originated from hydrothermal sedimentation, as proven by the $\mathrm{Fe} / \mathrm{Ti}$ ratios that averaged 25.70 , the $\mathrm{Fe}_{2} \mathrm{O}_{3} / \mathrm{FeO}$ ratios that averaged 1.45 , the $\mathrm{Ba} / \mathrm{Sr}$ ratios that averaged 33.34, the $\mathrm{V} /(\mathrm{V}+\mathrm{Ni})$ value that averaged 0.51 , the $(\mathrm{La} / \mathrm{Yb})_{\mathrm{N}}$ ratios that averaged 0.84 , and plotting in the hydrothermal category (Figures 7(a), 7(b), 7(c), 10, and 12). However, there were terrigenous materials or volcanic inputs during the hydrothermal sedimentation, which is supported by the $\mathrm{MgO}$ contents averaging $1.14 \%, \mathrm{Si} / \mathrm{Al}$ ratios averaging 9.13, $\mathrm{Al} /(\mathrm{Al}+\mathrm{Fe}+\mathrm{Mn})$ values averaging 0.63 , and $\mathrm{U} / \mathrm{Th}$ ratios averaging 0.87 . In addition, the terrigenous materials or volcanic inputs possibly contributed to lengthening cell parameters of the $\alpha$-quartz with isomorphous substitution of impurity elements (Figure 14(b)), which was also indicated by the existence of nonsilica impurities as well as the felsic minerals in the EBSD images (Figures 15(a) and 15(c)). In summary, the microfabric and geochemical characteristics strongly support a hydrothermal genesis for the siliceous rocks in the Dongxiang copper-polymetallic ore area. The siliceous rock arose from hydrothermal sedimentation, and the terrigenous or volcanic materials also contributed to the hydrothermal sedimentation to some extent. Additionally, the siliceous rocks of Qinzhou-Hangzhou joint belt in other published papers [48-50, 59, 95-97] all strongly supported 


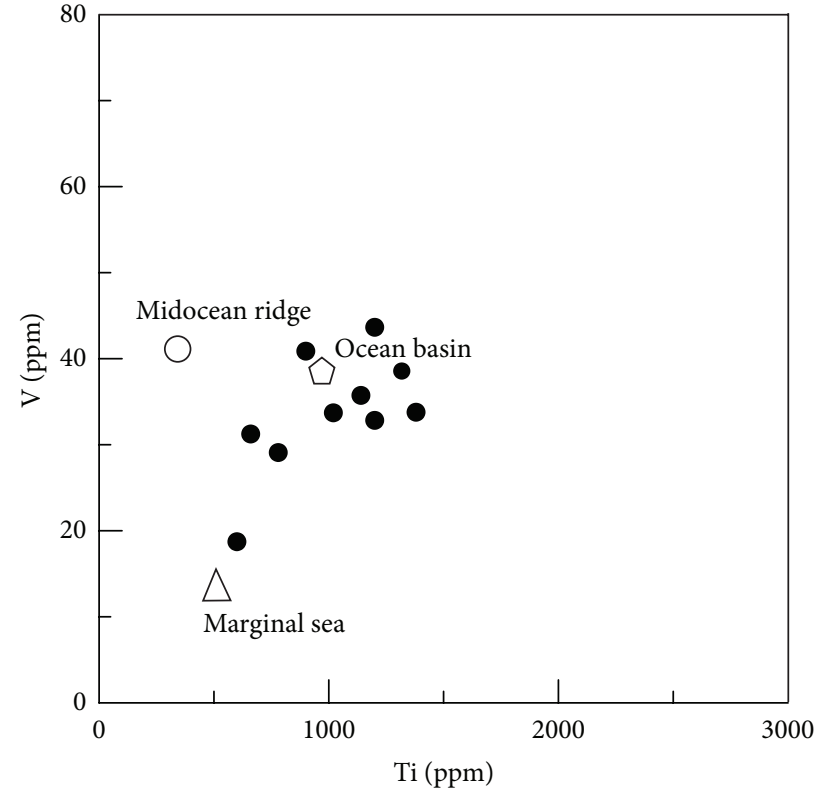

(a)

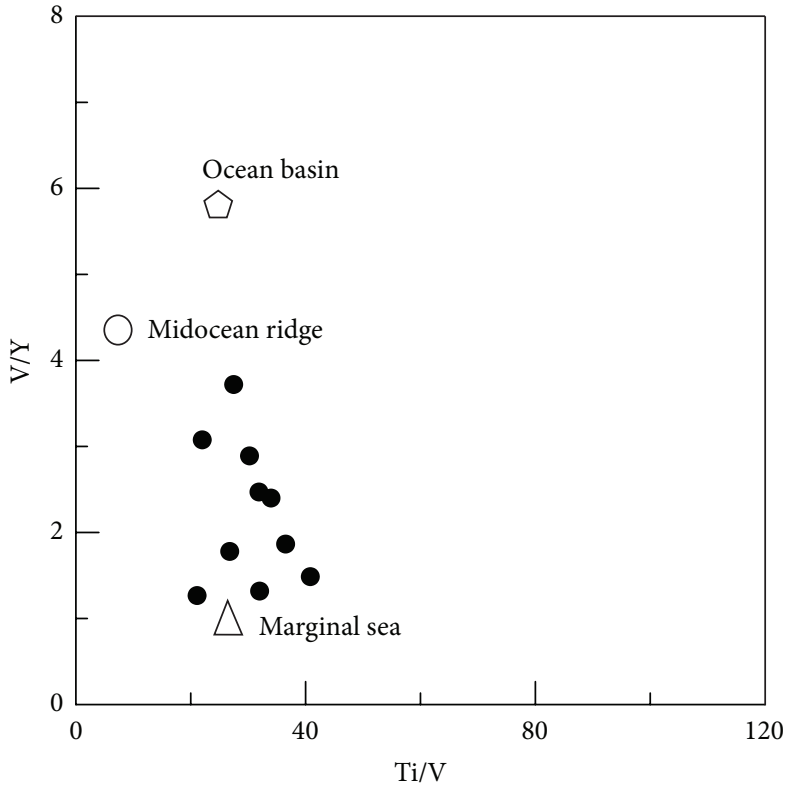

(b)

FIGURE 11: Trace element discrimination diagram by formation environment for siliceous rocks from Dongxiang (after [84]).

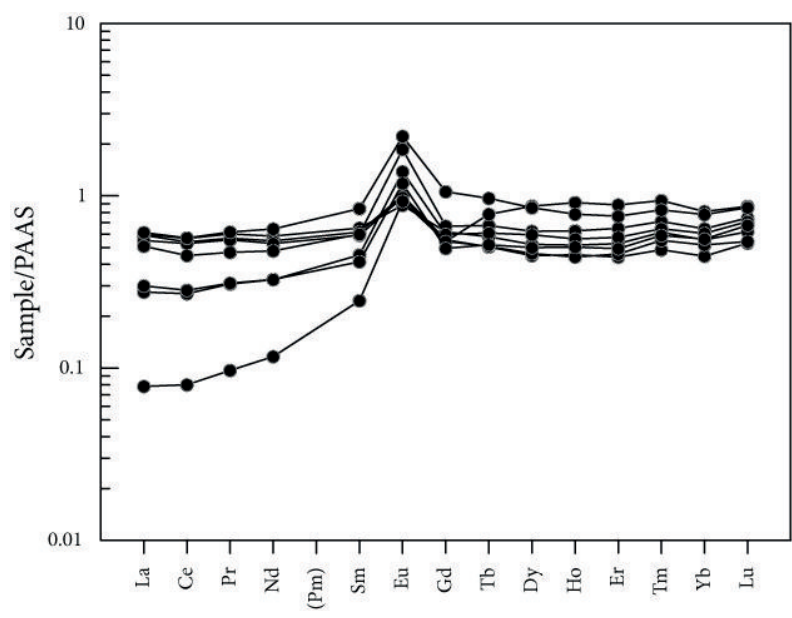

(a)

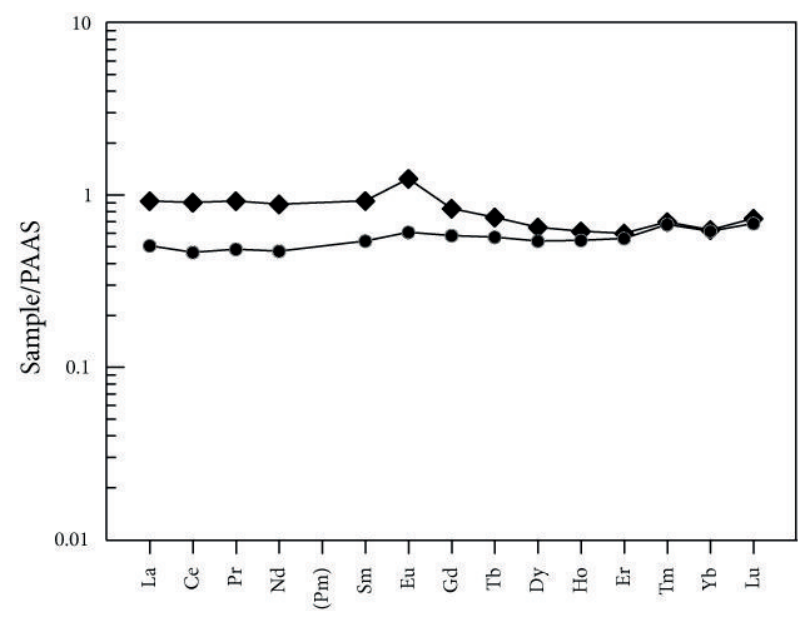

(b)

FIGURE 12: PAAS normalized REE patterns for siliceous rocks from Dongxiang.

the hydrothermal genesis of siliceous rocks. Therefore, the sedimentary siliceous rocks in the Dongxiang area originated from hydrothermal sedimentation.

There were slight contributions from biological activity during the hydrothermal sedimentation. The hydrothermal activities brought in a large number of the other elements with strong silicon affinity [98] and facilitated biological growth of a large quantity of biological organisms [99]. These organisms carried nonhydrothermal substances because of their lengthy migration and particular elemental needs (e.g., see [100]), and their deaths or metabolites joined in the deposition process with the hydrothermal sediment. This was why there were some samples falling into the biological categories
(Figures 7(c) and 9(a)). Although there was biological activity during the hydrothermal sedimentation, the contribution was too weak to affect the majority of the geochemical characteristics. Thus, the siliceous rocks have manifestly hydrothermal genesis with slight biological influences over their geochemical characteristics.

5.2. Formation Environment. The QHJB had a rift trough in the north segment and a subductional ocean basin in the south segment. The siliceous rocks in the Dongxiang copperpolymetallic ore area were formed in a basin of the marginal sea, as strongly supported by its geochemical characteristics, including an $\mathrm{Al} /(\mathrm{Al}+\mathrm{Fe}+\mathrm{Mn})$ values averaging 0.63 , 


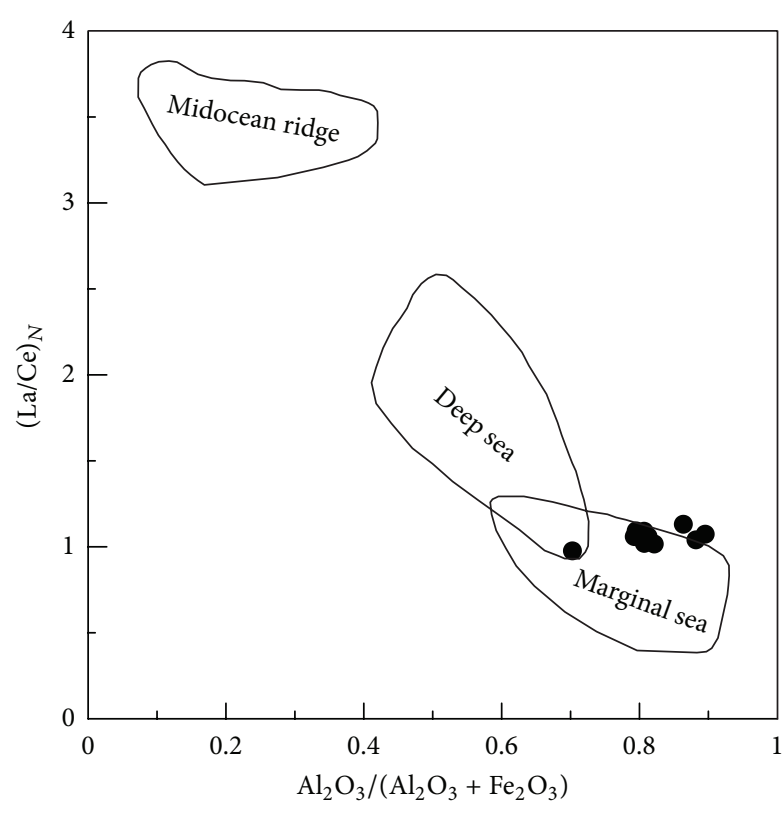

FIgURE 13: Major elements and REE discrimination diagram by formation environment for siliceous rocks from Dongxiang (after [73]).

$\mathrm{MnO} / \mathrm{TiO}_{2}$ values averaging 0.92, $\mathrm{Al}_{2} \mathrm{O}_{3} /\left(\mathrm{Al}_{2} \mathrm{O}_{3}+\mathrm{Fe}_{2} \mathrm{O}_{3}\right)$ values averaging $0.82, \mathrm{Sc} / \mathrm{Th}$ ratios averaging $1.19, \mathrm{Sr} / \mathrm{Ba}$ ratios averaging $0.07, \mathrm{REE}$ values averaging $92.46 \times 10^{-6}$, $\delta \mathrm{Ce}$ values averaging $0.94, \delta \mathrm{Eu}$ values averaging 2.04 , and $(\mathrm{La} / \mathrm{Lu})_{\mathrm{N}}$ ratios averaging 0.74 . In the geochemical discrimination diagrams, the siliceous rocks also fell into the basin of the marginal sea (Figures 8(a), 8(b), 11(b), and 13). The deposition occurred further away from the continent as the $\mathrm{U} / \mathrm{Th}$ ratios averaged 0.87 and $(\mathrm{La} / \mathrm{Yb})_{\mathrm{N}}$ ratios averaged 0.84 , which suggests an ocean basin as the most likely depositional site. According to the $\mathrm{Ti}-\mathrm{V}$ and $\mathrm{Ti} / \mathrm{V}-\mathrm{V} / \mathrm{Y}$ diagrams (Figures 11(a) and 11(b)), there is also evidence that the siliceous rocks formed in a basin of the marginal sea. Therefore, the siliceous rock in the Dongxiang area was most likely formed, in general, in a basin of the marginal sea. This ocean basin was limited in its width [83], which was possibly a rift trough due to the tensional setting [31]. In this study, the Neopalaeozoic tensional setting was indicated by the largescale development of Hercynian siliceous rocks (Figure 5), and the terrigenous input, taking part in the sedimentation of Devonian siliceous, to the basin was too narrow to reject the transference of materials from the continent to the basin. Although the siliceous rocks weakly exhibited deposition in the ocean basin category (Figure 11(a)), they were most likely affected by the magmatic activities during the Neopalaeozoic rifting. According to this, there should not be an ocean basin with subduction in the north segment of the QHJB, and the homochronous subduction of ocean basin [35] was possibly only in the south segment. Therefore, the QHJB, separating the Yangtze and Cathaysian plates, was diverse in different segments, which meant a rift trough in the north segment and an ocean basin with subduction in the south segment.
The ocean basin of the QHJB had a limited width in the north and middle segments. Together with the conjoining of Yangtze and Cathaysian ancient land crusts, the ocean basin of QHJB was closed in the Silurian [33]. Then, the Neodevonian uniform sedimentary veneer covered both the Yangtze and Cathaysian blocks, which is a disconformity in the Silurian strata [34]. Based on the ophiolitic melange in northeast Jiangxi province [28] and the Neopalaeozoic subduction in the south segment [35], there should be a narrow ocean basin that formed during rifting in a NE direction of the QHJB [56]. This ocean basin was composed of the Pingle depression and Qiantang depression in the north segment, which extended to Jiangxi province, south Hunan province, and ultimately the Qin-Fang ocean trough in southeast Guangxi province. Although there was an ocean basin, the width of the basin was too limited to resist the influence of terrigenous clastics. Because of the terrigenous materials, some samples deviated from the category of hydrothermal sedimentary siliceous rocks (Figures 7(a), 10, and 12(b)). According to the discrimination diagrams (Figures 16(a) and $16(\mathrm{~b}))$, the Carboniferous siliceous rocks in the north segment and the Permian siliceous rocks in the middle segment (Figure 2(a)) all fell into the marginal sea category, which indicates that the ocean basin was too limited because it came into being in both the north and middle segments. In addition, the north and middle segments were possibly relatively conformable in width. Hence, the ocean basin of the north and middle segments was limited in its width, which was too narrow to prevent the terrigenous sediment from joining the hydrothermal sedimentation process.

5.3. Hydrothermal Metallogenesis. Close relationships were exhibited between the siliceous rocks and the metal ore strata. Many ore deposits are distributed in the joint belt between diverse plates or terranes [101, 102], and the QHJB is per se not exceptional $[31,36]$. In the QHJB, there are many Neopalaeozoic metal sulphide deposits [103] that were formed in the taphrogenesis depression zone with territorial fracturing as the ore-controlling structure. Many of these ore deposits display close links with siliceous rocks that belong to VMS-type deposits [104], such as the metal sulphide ore deposits in areas of Yongping [105], Dongxiang [48], and Lehua [106]. This indicates the close relationship between metallogenesis and siliceous rocks, especially for the gold ore deposits and copper-polymetallic ore deposits [38]. In the Dongxiang copper-polymetallic ore deposit, the strata of siliceous rocks were distributed at the top of metal sulphide ore bodies or siliceous iron strata (Figure 3(b)), which denotes that the formation of metal sulphide (or siliceous iron) strata is generally followed by the silica strata as a series.

The siliceous rocks and metal sulphides both originated from hydrothermal sedimentation, and their formation had a close relationship with volcanism. During the hydrothermal sedimentation process, the volcanic magma could provide both energy and materials [107, 108]. In this study, the siliceous rocks indicated a tensional setting with siliceous rocks developing at a large scale (Figure 5), and the wide distribution of Neopalaeozoic siliceous rocks denoted a tensional setting in the Hercynian (Figure 6(b)). The tensional 


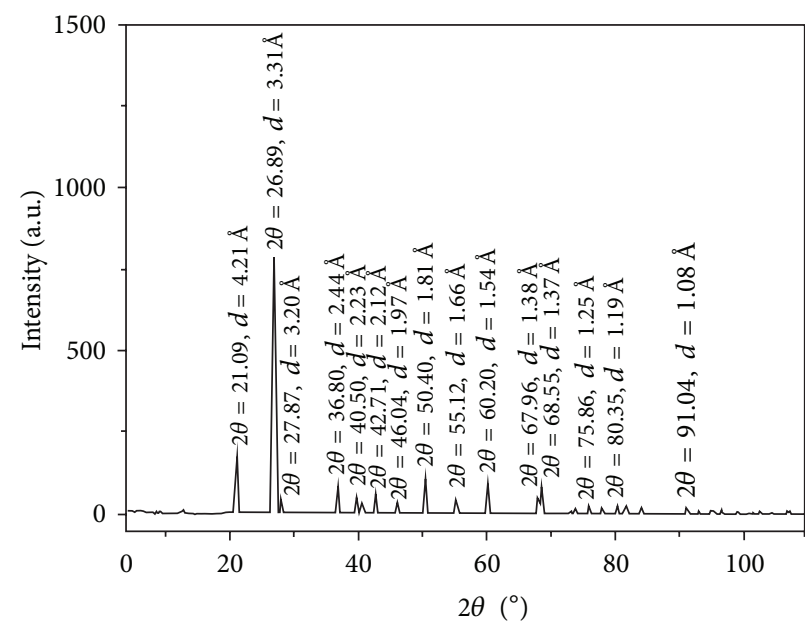

(a)

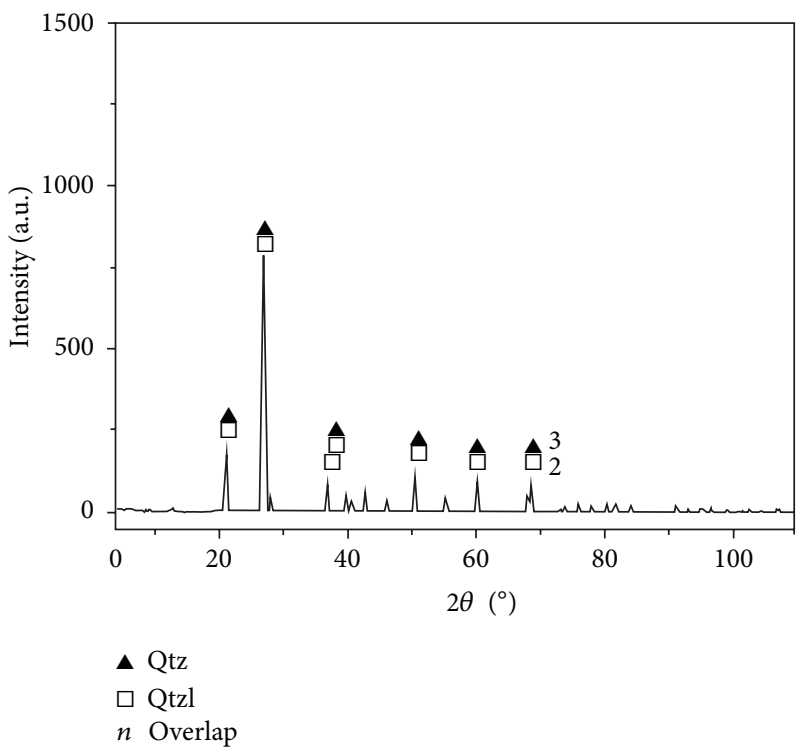

(b)

FIGURE 14: XRD diagram for siliceous rock from Dongxiang ((a) primary analytical result; (b) minerals matched their eight characteristic peaks).

setting facilitated magmatic activities that could provide the hydrothermal sedimentation with energy and possible material sources. This is strongly supported by the hydrothermal volcanic contribution of siliceous rocks, which is indicated by the $\mathrm{SiO}_{2} /\left(\mathrm{K}_{2} \mathrm{O}+\mathrm{Na}_{2} \mathrm{O}\right)$ values averaging $35.05, \mathrm{Al}_{2} \mathrm{O}_{3} / \mathrm{TiO}_{2}$ ratios averaging 50.03, and the associated geochemical discrimination diagrams (Figures 9(a) and 9(b)). In addition, the $\mathrm{K}_{2} \mathrm{O} / \mathrm{Na}_{2} \mathrm{O}$ and $\mathrm{SiO}_{2} / \mathrm{MgO}$ values deviate from those of typical volcanic siliceous rock, which is possibly because of the contribution of biological factors (Figure 9(a)) and terrigenous inputs. Similar to the geological characteristics of another ore deposit in the nearby Yongping area (Figure 3(a)) $[105,109]$, these ore deposits had ${ }^{206} \mathrm{~Pb} /{ }^{204} \mathrm{~Pb}$ ratios ranging from 17.351 to $18.309,{ }^{207} \mathrm{~Pb} /{ }^{206} \mathrm{~Pb}$ ratios ranging from 15.416 to 15.661, and ${ }^{208} \mathrm{~Pb} /{ }^{204} \mathrm{~Pb}$ values ranging from 37.703 to 38.331 . Thus, the lead isotope values indicated sources between the upper crust and mantle, and the formation was dated from $330 \mathrm{Ma}$ to $609 \mathrm{Ma}$. In addition, the $\delta^{34} \mathrm{~S}$ values ranged from $-10.2 \%$ to $+2.7 \%$, which agreed with those of the massive sulphide deposits in volcanic thermal springs. As with classic VMS deposits [107, 110, 111], the aforementioned geochemical Yongping characteristics indicated that the oreforming metal elements came from both volcanic rocks and lower strata, whereas the elemental sulphur came from the convective sea water. Thus, both the siliceous rocks and the metal sulphides arose from hydrothermal sedimentation, and the ore-forming metal elements originated from the lower strata and volcanic rocks. During the convection process, the convective sea water, heated by the lower magmatism, leached the ore-forming metal materials from the lower strata and volcanic rocks. Ultimately, the ore-forming metal materials were precipitated when the hydrothermal water was mixed with the cold seawater with decreasing solubility.
5.4. Sedimentary Sequence. The hydrothermal sedimentation process evolved cyclically because of the release of internal energy. The current hydrothermal activities at the ocean bottom were divided into high-temperature black smoker activity (hydrothermal water including mainly massive sulphide) at $400^{\circ} \mathrm{C}$ to $350^{\circ} \mathrm{C}$, medium-temperature white smoker activity (hydrothermal water including silica, barite, and gypsum, among other minerals) at 300 to $100^{\circ} \mathrm{C}$, and low-temperature spillway activity (hydrothermal water including pure silica) at below $100^{\circ} \mathrm{C}[112]$. The siliceous rocks and metal sulphides were thus formed at different temperatures, which involves a different evolution process with hydrothermal sedimentation at different temperatures. According to the geological sketch histogram (Figure 3(b)), the siliceous rocks were present in alternating layers, as were wall rocks and metal sulphide (or siliceous iron) strata, and the strata of siliceous rocks overlaid conformably the massive sulphide or siliceous iron formation all the time. At the bottom of the sulphide strata, there were conformable tuff strata that overlaid the marine volcanic rocks. As a whole, there were several sedimentary cycles in the Dongxiang ore deposit, and each of the cycles possibly involved marine volcanic rocks, volcanic tuff, metal sulphide, and siliceous rocks from the bottom to the top. Thus, the hydrothermal sedimentary strata, as well as the other sedimentary rocks, display periodic sedimentation in the Dongxiang area, including siliceous rocks and massive metal sulphides.

Sedimentary cycles act as an indication of interior dynamic geological evolution. From the bottom to the top, each sedimentary cycle included marine volcanic rock, volcanic tuff, ore strata (including massive sulphide or siliceous iron), and siliceous rock. The normal marine sedimentary rocks (e.g., limestone, mudstone, or clastic rocks) were formed 


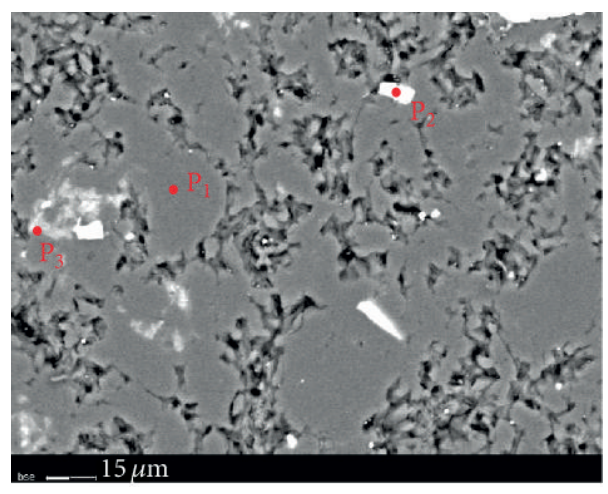

(a)

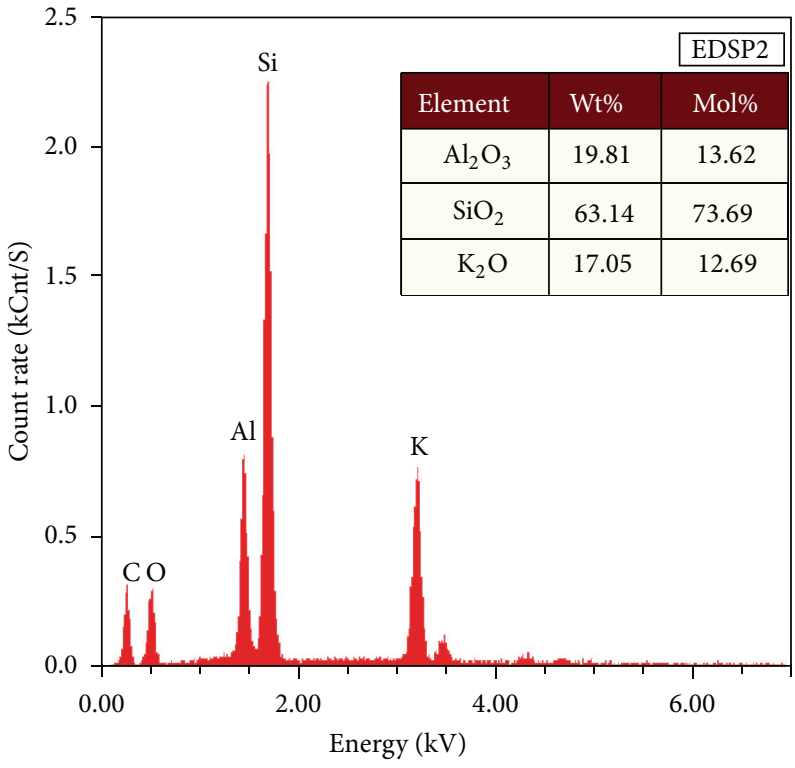

(c)

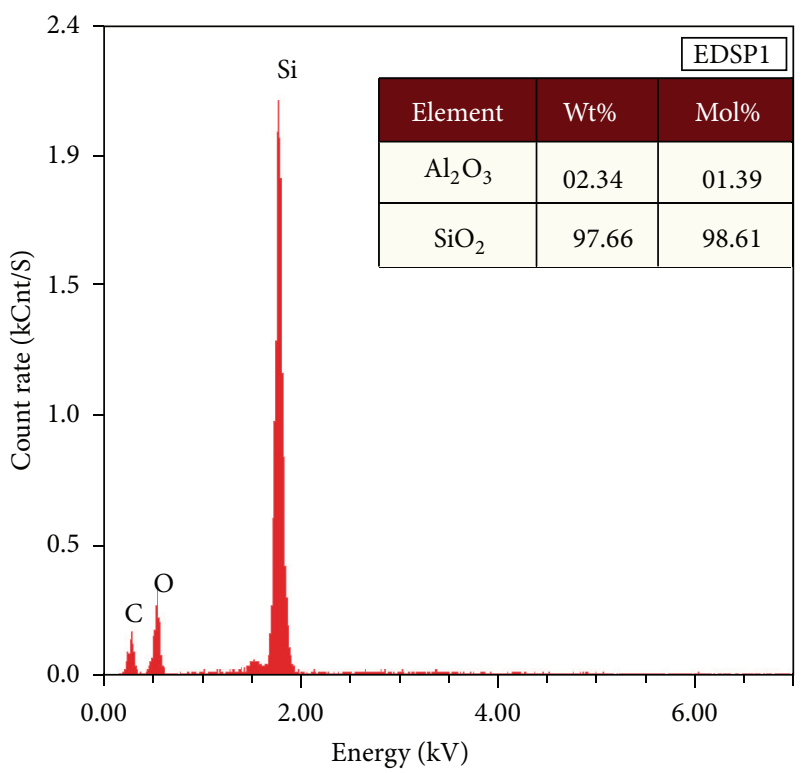

(b)

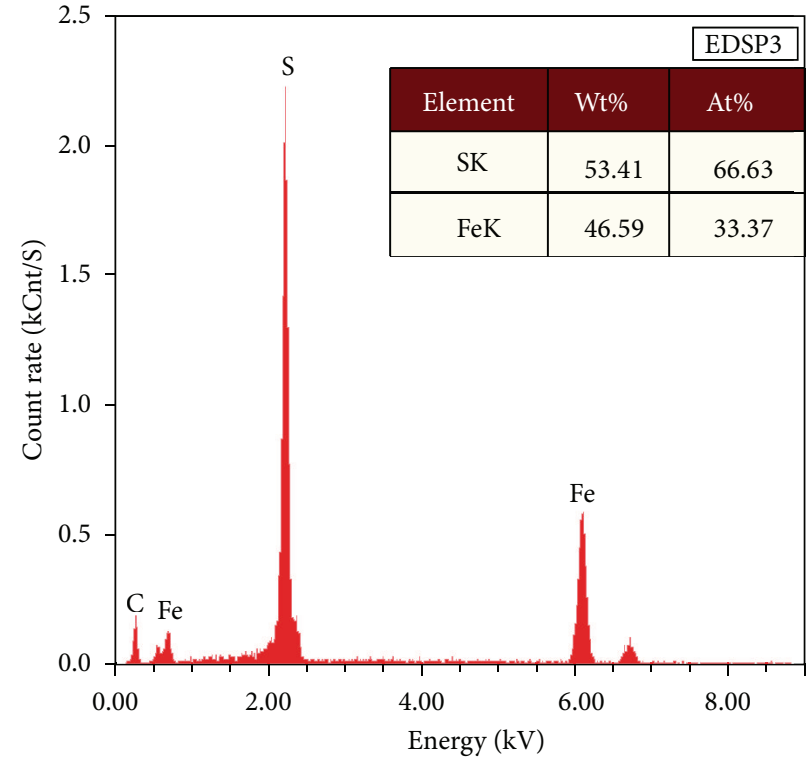

(d)

FIGURE 15: EBSD images and EDS result of the siliceous rock from Dongxiang.

at the end of the continuous sedimentary sequence, which was related to the interior dynamic geological evolution. Therefore, the sedimentary sequence in the Dongxiang area could be divided into several cycles that represent the release of energy from the inner earth. In every normal sedimentary cycle, the internal energy was released rapidly at first with high intensity and then slowed down gradually as the cycle continued. The initial energy released was stronger with the volcanic eruption and associated ash, and this contributed to the development of volcanic rocks followed by the volcanic breccias or tuff at the ocean bottom. After the volcanic eruption, there was high-temperature hydrothermal water with the metal sulphides as the main precipitation. The ore strata were formed at this time. When the release of energy from the inner earth became less violent, the hydrothermal water changed to become silica-rich and lacking in metal sulphides with a relatively lower temperature. In addition, the sedimentary sequences for the hydrothermal activities should be distinct if they arose from different geological settings. If the volcanism was too weak to produce volcanic ash or stagnates and was suddenly without volcanic ash, the volcanic tuff layer would disappear with a sedimentary sequence, including marine volcanic rock, massive sulphides, and siliceous rocks. In another scenario, if the energy coming from interior magmatism was too weak to ensure a hightemperature sulphide smoker immediately after the volcanic 


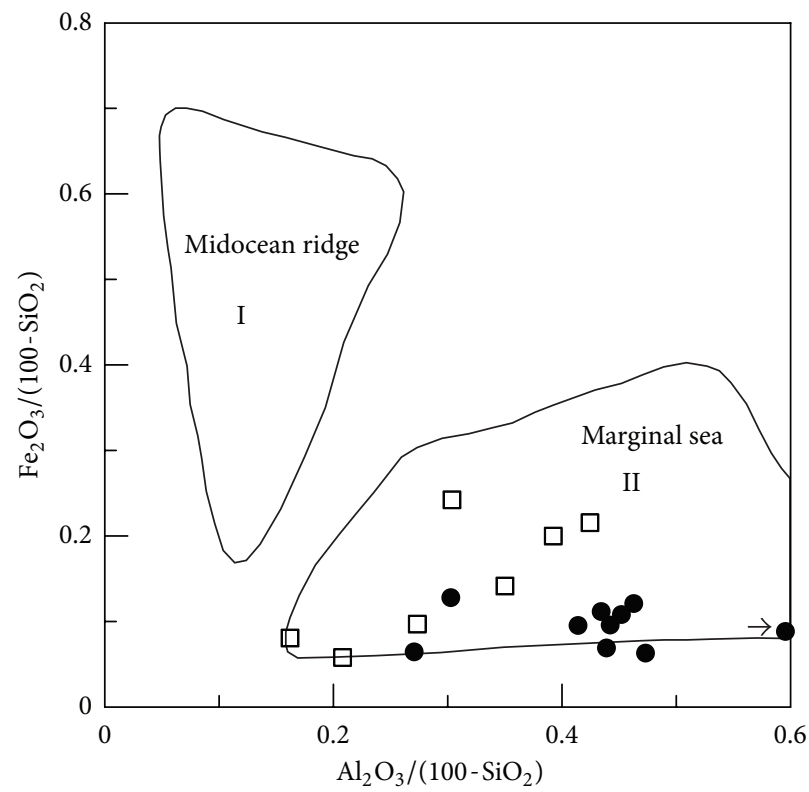

North segment

$\square$ Middle segment

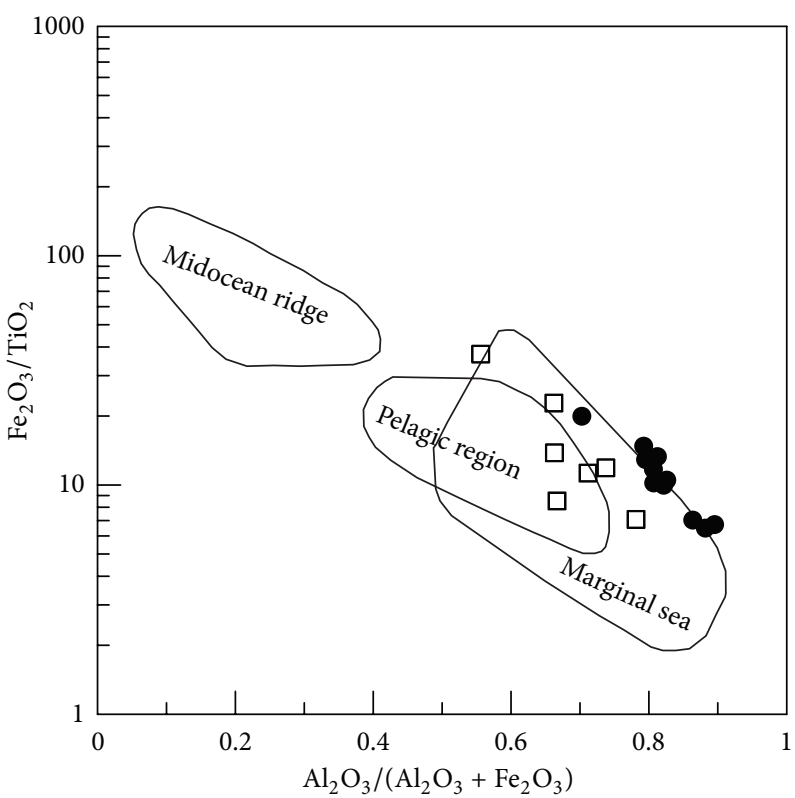

(b)

FIGURE 16: Discrimination diagram of the north and middle QHJB (data of middle segment from [96]; north segment data from this paper).

eruption, there might be a sedimentary sequence with marine rocks, volcanic tuff, and siliceous rocks from the bottom to the top. In conclusion, the marine sedimentary rocks, including those marine volcanic rocks, volcanic tuff, metal sulphides, and siliceous rocks, were contributed by the release of internal energy from the earth, and their combined sequences represent the cyclic release of internal energy.

\section{Conclusions}

(1) The siliceous rocks originated from hydrothermal sedimentation. The siliceous rocks had $\mathrm{SiO}_{2}$ contents ranging from $77.13 \%$ to $87.80 \%$ with an average of $80.41 \%$ and exhibited hydrothermal genesis for their quartz grains with low crystallinity, less automorphism, and a close-packed texture. Identifiably hydrothermal characteristics were also observed in the geochemical composition, such as the $\mathrm{Ba}$ averaging $1008.61 \times 10^{-6}$, $\mathrm{U}$ averaging $4.42 \times 10^{-6}$, $\Sigma \mathrm{REE}$ values averaging $92.46 \times 10^{-6}, \mathrm{Fe} / \mathrm{Ti}$ ratios averaging 25.70, $\mathrm{Al} /(\mathrm{Al}+\mathrm{Fe}+\mathrm{Mn})$ values averaging $0.63,(\mathrm{Fe}+\mathrm{Mn}) / \mathrm{Ti}$ values averaging 26.89, $\mathrm{Fe}_{2} \mathrm{O}_{3} / \mathrm{FeO}$ ratios averaging $1.45, \mathrm{Ba} / \mathrm{Sr}$ ratios averaging 33.34, and $(\mathrm{La} / \mathrm{Yb})_{\mathrm{N}}$ values averaging 0.84 .

(2) The Neopalaeozoic Qinzhou-Hangzhou joint belt was diverse in different segments, and the siliceous rocks of the north Qinzhou-Hangzhou joint belt were deposited in a basin of the marginal sea. The siliceous rocks were formed in the marginal sea, which is indicated by $\mathrm{MnO} / \mathrm{TiO}_{2}$ ratios averaging $0.92, \mathrm{Al} /(\mathrm{Al}+\mathrm{Fe})$ values averaging 0.64 , $\mathrm{Sc} / \mathrm{Th}$ ratios averaging $1.19, \mathrm{U} / \mathrm{Th}$ ratios averaging 0.87 , and $\delta \mathrm{Ce}$ values averaging 0.94 . In addition, the ocean basin of the north and middle segments of Qinzhou-Hangzhou joint belt was limited in its width without subduction and accordingly could not resist terrigenous input during the hydrothermal sedimentation.

(3) The siliceous rock exhibited close relationships with volcanic activity, which could provide energy and material sources. The hydrothermal sedimentation of the siliceous rocks was influenced by volcanic activity, and this was indicated by $\mathrm{SiO}_{2} /\left(\mathrm{K}_{2} \mathrm{O}+\mathrm{Na}_{2} \mathrm{O}\right)$ values averaging 35.05 and $\mathrm{Al}_{2} \mathrm{O}_{3} / \mathrm{TiO}_{2}$ values averaging 50.03. The sedimentary rocks of the Dongxiang copper-polymetallic ore deposit are the product of the release of internal earth energy, and their alternative existence represents cyclical earth energy release.

(4) There are two types of cell parameters for the $\alpha$ quartz grains. In the siliceous rocks, the majority mineral was $\alpha$-quartz with two types of crystal cell parameters. The first type of $\alpha$-quartz had Pdf card number 75-0443 and space group P3121(152) with agreement to standard $\alpha$-quartz, whereas the other type of $\alpha$-quartz had Pdf card number 650466 and space group P3221(154) with slightly elongated cell parameters.

\section{Acknowledgments}

This study is financially supported by the Natural Science Foundation of China (Grant 41303025), the 973 Program of China (Grant 2012CB406601), the Natural Science Foundation of China (Grant 41373025, 41273040), Guangdong Provincial Natural Science Foundation (Grant S2013010012528), and the Subject and Special Fund of 
the Ministry of Science and Technology of The State Key Laboratory of Geological Processes and Mineral Resources (Grant GPMR200804).

\section{References}

[1] M. G. Yang, Law and Prediction for Metallogenesis of LuoxiaoWuyi Uplift and Chenzhou-Shangrao Sag, Geological press, Beijing, China, 1998.

[2] J. S. Ren, T. Y. Chen, Z. G. Liu, B. G. Niu, and F. R. Liu, "Several question to geotectonic in South China," Chinese Sicence Bulletin, no. 1, pp. 49-51, 1986.

[3] J. S. Ren, "New view to geotectonic evolution of East China and its neighbouring area," Regional Geology of China, no. 4, pp. 289-300, 1989.

[4] J. S. Ren, "On the geotectonocs of Southern China," Acta Geological Sinica, vol. 64, no. 4, pp. 275-288, 1990.

[5] B. Xu, "Discussion on trench arc basin system in Northeast Jiangxi-South Anhui Province," Acta Geologica Sinica, no. 1, pp. 33-41, 1990.

[6] L. Z. Guo, L. S. Shu, H. F. Lu et al., "A synthetical review on research advances on the terrane tectonics in China," Journal of Nanjing University, vol. 36, no. 1, pp. 1-17, 2000.

[7] L. Z. Guo, S. Shi Yang, R. Ma, Y. S. Fu, and H. Lu, "Study on terrane structure in Southeast China," Journal of Nanjing University, vol. 20, no. 4, pp. 732-737, 1984.

[8] D. G. Yu, T. Y. Guan, and G. F. Huang, Characteristics of Late Proterozoic Rift System and Formation and Evolution of JinningCaledon Sea Basin South(East) China, Atomic Energy Press, Beijing, China, 2000.

[9] C. M. Bao, H. G. Xu, and G. H. Chen, "The division and correlation of South China orogen stratigraphy and discussion of Nanhua system base boundary," Resources Survey \& Environment, vol. 23, no. 2, pp. 84-87, 2002.

[10] Y. Zeng and M. G. Yang, "Central Jiangxi collision melange zone," Regional Geology of China, vol. 18, no. 1, pp. 17-22, 1999.

[11] J. H. Xu and Q. X. He, "Shell plate tectonic mode and collisional orogen," Science in China A, no. 11, pp. 1081-1089, 1980.

[12] J. H. Xu, "Several questions of geotectonic in South China," Geological Science and Technology Information, vol. 6, no. 2, pp. 13-27, 1987.

[13] L. J. Li Jiliang, S. S. Sun Shu, K. J. Hsu, C. H. Chen Haihong, P. H. Peng Haipo, and W. Q. Wang Qingchen, "New evidence about the evolution of the South Cathay orogenic belt," Scientia Geologica Sinica, vol. 2, no. 3, pp. 217-225, 1989.

[14] L. S. Shu, Y. S. Shi, L. Z. Guo, J. Charvet, and Y. Sun, Central Plate in Jiangnan-Terrane Structure and Collisional Orogeny Kinematics, Nanjing University Press, Nanjing, China, 1995.

[15] Z. X. Li, X. H. Li, P. D. Kinny, and J. Wang, "The breakup of Rodinia: did it start with a mantle plume beneath South China?" Earth and Planetary Science Letters, vol. 173, no. 3, pp. 171-181, 1999.

[16] D. K. Xie, R. S. Ma, Y. S. Zhang et al., Growth Process of South China Continental Crust and Mantle Plume Structure, Geological Press, Beijing, China, 1996.

[17] Tectonic map compiling group, Institute of geology, Academia sinica, "A preliminary note on the basic tectonic features and their developments in China," Chinese Journal of Geology, no. 1, pp. 1-17, 1974.
[18] J. H. Xu, S. Sun, and J. L. Li, "Be orogen in South China, not South China platform," Science in China B, vol. 17, no. 10, pp. 1107-1115, 1987.

[19] F. H. Lou, Z. Z. Huang, Z. R. Song, and X. H. Wu, "Geotectonic evolution modal of the middle-new proterozoic orogenic belt in the central part of South China," Geological Survey and Research, vol. 26, no. 4, pp. 200-206, 2003.

[20] R. S. Ma, "New thought about the tectonic evolution of the South China: with discussion on several problems of the cathaysian old land," Geological Journal of China Universities, vol. 12, no. 4, pp. 448-456, 2006.

[21] B. Xia, "A study on geochemical characteristic and emplaced style of two different ophiolites of later proterzoic xuefeng stage in the Longsheng regions, Guangxi Southeast China," Journal of Nanjing University, no. 3, pp. 554-566, 1984.

[22] X.-H. Li, J.-X. Zhao, M. T. McCulloch, G.-Q. Zhou, and F.M. Xing, "Geochemical and Sm-Nd isotopic study of neoproterozoic ophiolites from Southeastern China: petrogenesis and tectonic implications," Precambrian Research, vol. 81, no. 1-2, pp. 129-144, 1997.

[23] S. Peng, Z. Jin, J. Fu, L. He, M. Cai, and Y. Liu, "The geochemical evidences and tectonic significance of neoproterozoic ophiolite in Yunkai area, Western Guangdong Province, China," Acta Geologica Sinica, vol. 80, no. 6, pp. 814-825, 2006.

[24] X. M. Zhou and D. Z. Wang, "The peraluminous granodiorites with low initial $\sim(87) \mathrm{Sr} / \sim(86) \mathrm{Sr}$ ratio and their genesis in Southern Anhui Province, Eastern China," Acta Petrologica Sinica, no. 3, pp. 37-45, 1988.

[25] X. M. Zhou, H. B. Zou, J. D. Yang, and Y. X. Wang, "Sm-Nd isochronous age of Fuchuan ophiolite suite in Shexian county, Anhui Province and its geological significance," Chinese Science Bulletin, no. 3, p. 208, 1990.

[26] X. M. Zhou, Y. H. Zhu, and J. G. Chen, "Discovery of ultramafic obiculite and its genesis," Chinese Science Bulletin, vol. 35, no. 8, pp. 604-606, 1990.

[27] H. R. Wu, "Tectonopalaeogeographic analysis of the geologic problems related to ophiolitic belt in Northeastern Jiangxi Province," Journal of Palaeogeography, vol. 5, no. 3, pp. 328-342, 2003.

[28] C. Zhao, K. He, X. Mo et al., "Discovery and its significance of late paleozoic radiolarian silicalite in ophiolitic melange of Northeastern Jiangxi deep fault belt," Chinese Science Bulletin, vol. 41, no. 8, pp. 667-670, 1996.

[29] J. Zhou, X. Wang, J. Qiu, and J. Gao, "Lithogeochemistry of meso- and neoproterozoic mafic-ultramafic rocks from Northern Guangxi," Acta Petrologica Sinica, vol. 19, no. 1, pp. 9-18, 2003.

[30] X. F. Qin, F. S. Zhou, G. A. Hu et al., "First discovery of MORB volcanic rock and its tectonic significance on the North Margin of the Yunkai Block, Southeastern Guangxi," Geological Science and Technology Information, vol. 24, no. 3, pp. 20-24, 2005.

[31] J. W. Mao, M. H. Chen, S. D. Yuan, and C. L. Guo, "Geological characteristics of the Qinhang (or Shihang) metallogenic belt in South China and spatial-temporal distribution regularity of Mineral deposits," Acta Geologica Sinica, vol. 85, no. 5, pp. 636658, 2011.

[32] L. S. Shu, "Predevonian tectonic evolution of South China: from cathaysian block to caledonian period folded orogenic belt," Geological Journal of China Universities, vol. 12, no. 4, pp. 418431, 2006.

[33] M. G. Yang and Y. W. Mei, "Characteristics of geology and metallization in the Qinzhou-Hangzhou plaeoplate Juncture," 
Geology and Mineral Resource of South China, vol. 9, no. 3, pp. 52-59, 1997.

[34] Z. R. Hu and G. H. Deng, "Tectonic characteristics of the Qinzhou-Hangzhou joint belt," Journal of East China Institute of Technology, vol. 32, no. 2, pp. 114-122, 2009.

[35] X. F. Qin, Z. Q. Wang, Y. L. Zhang, L. Z. Pan, G. A. Hu, and F. S. Zhou, "Geochronology and geochemistry of Early Mesozoic acid volcanic rocks from Southwest Guangxi: constraints on tectonic evolution of the southwestern segment of QinzhouHangzhou joint belt," Acta Petrologica Sinica, vol. 27, no. 3, pp. 794-808, 2011.

[36] Y. Z. Zhou, C. Y. Zeng, H. Z. Li et al., "Geological evolution and ore-prospecting targets in southern segment of Qinzhou Bay-Hangzhou bay juncture orogenic belt," Geological Bulletin of China, vol. 31, no. 2-3, pp. 32-37, 2012.

[37] J. Liang, H. Z. Li, and C. Y. Zeng, "Discussion on metallogenesis inhomogeneity of Qin-Hang metallogenic belt," Geology and Tectonic, p. 288, 2011.

[38] H. Z. Li, Chert sedimentary system and its indications on tectonic evolution, petrogenesis and mineralization in Northern and Southern Margins of Yangtze Platform, China [Ph.D. dissertation], Sun Yat-Sen university, Guangzhou, China, 2012.

[39] J. Liang, Y. Z. Zhou, H. Z. Li et al., "Geological characteristics and genesis of porphyry copper deposits in Qin-Hang suture zone, South China," Acta Petrologica Sinica, vol. 28, no. 10, pp. 3361-3372, 2012.

[40] S. Huang j, J. M. Ma D, and X. - Len, “The strontium isotopes of deep-sea siliceous rocks from earlier carboniferous to earlier permian, Qinzhou, Guangxi," Acta Sedimentologica Sinica, vol. 17, no. 4, pp. 542-546, 1999.

[41] Y.-X. Qiu and X.-Q. Liang, "Evolution of basin-range coupling in the Yunkai Dashan-Shiwan Dashan area, Guangdong and Guangxi: with a discussion of several tectonic problems of South China," Geological Bulletin of China, vol. 25, no. 3, pp. 340-347, 2006.

[42] M. Baltuck, "Provenance and distribution of tethyan pelagic and hemipelagic siliceous sediments, pindos mountains, Greece," Sedimentary Geology, vol. 31, no. 1, pp. 63-88, 1982.

[43] R. W. Murray, M. R. B. Ten Brink, D. L. Jones, D. C. Gerlach, and P. G. Russ, "Rare earth elements as indicators of different marine depositional environments in chert and shale," Geology, vol. 18, no. 3, p. 268, 1990.

[44] G. H. Girty, D. L. Ridge, C. Knaack, D. Johnson, and R. K. AlRiyami, "Provenance and depositional setting of paleozoic chert and argillite, Sierra Nevada, California," Journal of Sedimentary Research, vol. 66, no. 1, pp. 107-118, 1996.

[45] H. Li, Y. Zhou, Z. Yang et al., "Geochemical characteristics and their geological implications of cherts from Bafangshan-Erlihe area in Western Qinling Orogen," Acta Petrologica Sinica, vol. 25, no. 11, pp. 3094-3102, 2009.

[46] H. Z. Li, Y. Z. Zhou, L. C. Zhang et al., "Study on geochemistry and development mechanism of proterozoic chert from Xiong'er group in Southern Region of North China craton," Acta Petrologica Sinica, vol. 28, no. 11, pp. 3679-3691, 2012.

[47] Y. Zhou, W. Fu, Z. Yang et al., "Geochemical characteristics of mesozoic chert from Southern Tibet and its petrogenic implications," Acta Petrologica Sinica, vol. 24, no. 3, pp. 600-608, 2008.

[48] Y. T. Xu, "The origin and geochemical characteristics of sedimentary silicalites in dongxiang mine Jiangxi Province," Acta Sedimentologica Sinica, vol. 15, no. 3, pp. 110-114, 1997.
[49] Y. T. Xu, "The geochemical characteristics of hydrothermal sediment chert of the late proterozoic era and their sedimentary environmental implication in Xiqiu area, Zhejiang Province," Geochemistry, vol. 25, no. 6, pp. 600-608, 1996.

[50] X. Y. Xu Yuetong, “The geochemical characteristics of cherts in the Carboniferous period and their sedimentary environment implications," Scientia Geological Sinica, vol. 33, no. 1, pp. 3950, 1998.

[51] H. F. Ling, B. T. Zhang, W. Z. Shen, and Z. H. Zhang, "Crustal Basement evolutionof the Zhejiang-Jiangxi portion of the Jiangnan proterozoic island arc zone," Geotectonica et Metallogenia, vol. 17, no. 2, pp. 147-152, 1993.

[52] S. N. Yang, "Presinian palaeotectonic framework of Yangtse massif and its continental margin," Jiangxi Geology, vol. 2, no. 2, pp. 167-175, 1988.

[53] X. K. Zhao, Z. Q. Yong, G. R. Li, X. B. Zhang, G. J. Deng, and $\mathrm{K}$. Li, "Residual basin of passive continental margin-a neglected basin type," Oil \& Gas Geology, vol. 28, no. 1, pp. 121-128, 2007.

[54] C. M. Powell, Z. X. Li, and M. W. McElhinny, "Paleomagnetic constraints on timing of the Neoproterozoic breakup of Rodinia and the Cambrian formation of Gondwana," Geology, vol. 21, no. 10, pp. 889-892, 1993.

[55] X. H. Li, X. C. Wang, W. X. Li, and Z. X. Li, "Petrogenesis and tectonic significance of Neoproterozoic basaltic rocks in South China from orogenesis to intracontinental rifting," Geochemica, vol. 37, no. 4, pp. 382-398, 2008.

[56] H.-D. Chen, M.-C. Hou, W.-J. Liu, and J.-C. Tian, "Basin evolution and sequence stratigraphic framework of South of China during Hercynian cycle to Indo-Chinese epoch," Journal of Chengdu University of Technology, vol. 31, no. 6, pp. 629-635, 2004.

[57] Z. X. Li, L. H. Zhang, and C. M. Powell, "South China in Rodinia: part of the missing link between Australia-East Antarctica and Laurentia?" Geology, vol. 23, no. 5, pp. 407-410, 1995.

[58] G. L. Zhang and G. C. He, "The tectonic geochemistry and prospecting characters of fault zone in Dongxiang copper deposit," Geology and Prospecting, vol. 38, no. 6, pp. 22-24, 2002.

[59] Y. Z. Zhou, "Sedimentary geochemical characteristics of cherts of Danchi basin in Guangxi Province," Acta Sedimentologica Sinica, no. 3, pp. 75-83, 1990.

[60] Guangdong Bureau of Geology and Mineral Resources, Regional Geology of Guangdong Province, Geological Publishing House, Beijing, China, 1988.

[61] Guangxi Zhuang Nationality Autonomous Region Bureau of Geology and Mineral Resources, Regional Geology of Guangxi Zhuang Nationality Autonomous Region, Geological Publishing House, Beijing, China, 1985.

[62] Hunan Bureau of Geology and Mineral Resources, Regional Geology of Hunan Province, Geological Publishing House, Beijing, China, 1988.

[63] Jiangxi Bureau of Geology and Mineral Resources, Regional Geology of Jiangxi Province, Geological Publishing House, Beijing, China, 1984.

[64] Zhejiang Bureau of Geology and Mineral Resources, Regional Geology of Zhejiang Province, Geological Publishing House, Beijing, China, 1989.

[65] S. M. Mclennan, "Rare earth elements in sedimentary rocks: influences of provenance and sedimentary processes. Geochemistry and mineralogy of rare earth elements," in Reviews in Mineralogy, B. R. LiPin and G. A. McKay, Eds., vol. 21, pp. 169-200, 1989. 
[66] S. R. Taylor and S. M. McLennan, The Continental Crust: Its Composition and Evolution, Blackwell Scientific Publications, Oxford, UK, 1985.

[67] R. W. Murray, M. R. Buchholtz Ten Brink, D. C. Gerlach, G. Price Russ III, and D. L. Jones, "Rare earth, major, and trace element composition of Monterey and DSDP chert and associated host sediment: assessing the influence of chemical fractionation during diagenesis," Geochimica et Cosmochimica Acta, vol. 56, no. 7, pp. 2657-2671, 1992.

[68] K. Boström and M. N. A. Peterson, "The origin of aluminumpoor ferromanganoan sediments in areas of high heat flow on the East Pacific Rise," Marine Geology, vol. 7, no. 5, pp. 427-447, 1969.

[69] R. Sugisaki, K. Yamamoto, and M. Adachi, "Triassic bedded cherts in central Japan are not Pelagic," Nature, vol. 298, no. 5875, pp. 644-647, 1982.

[70] P. A. Rona, "Hydrothermal mineralization at oceanic ridges," Canadian Mineralogist, vol. 26, pp. 431-465, 1988.

[71] G. L. Zhang and H. Y. Cai, "Discussion on origin of Dachang polymetallic ore deposit in Guangxi Province," Geological Review, vol. 33, no. 5, pp. 426-436, 1987.

[72] K. Yamamoto, "Geochemical characteristics and depositional environments of cherts and associated rocks in the Franciscan and Shimanto Terranes," Sedimentary Geology, vol. 52, no. 1-2, pp. 65-108, 1987.

[73] R. W. Murray, "Chemical criteria to identify the depositional environment of chert: general principles and applications," Sedimentary Geology, vol. 90, no. 3-4, pp. 213-232, 1994.

[74] M. Adachi, K. Yamamoto, and R. Sugisaki, "Hydrothermal chert and associated siliceous rocks from the Northern Pacific their geological significance as indication od ocean ridge activity," Sedimentary Geology, vol. 47, no. 1-2, pp. 125-148, 1986.

[75] T. Z. Tang Zhaohui and Z. Y. Zeng Yunfu, "Petrology, geochemistry and origin of cherts in the uraniferous formations, middle silurian, West Qinling range," Acta Petrologica Sinica, vol. 2, pp. 62-71, 1990.

[76] F. X. Zhang, "The recognition and exploration significance of exhalites related to $\mathrm{Pb}-\mathrm{Zn}$ mineralizations in Devonian formations in Qinling mountains," Geology and Prospecting, vol. 25, no. 5, pp. 11-18, 1989.

[77] B. L. Weaver and J. Tarney, "Empirical approach to estimating the composition of the continental crust," Nature, vol. 310, no. 5978, pp. 575-577, 1984.

[78] V. Marchig, H. Gundlach, P. Möller, and F. Schley, "Some geochemical indicators for discrimination between diagenetic and hydrothermal metalliferous sediments," Marine Geology, vol. 50, no. 3, pp. 241-256, 1982.

[79] J. M. Peter and S. D. Scott, "Mineralogy, composition, and fluidinclusion microthermometry of seafloor hydrothermal deposits in the southern trough of Guaymas Basin, Gulf of California," Canadian Mineralogist, vol. 26, pp. 567-587, 1988.

[80] K. M. Yarincik, R. W. Murray, T. W. Lyons, L. C. Peterson, and G. H. Haug, "Oxygenation history of bottom waters in the Cariaco Basin, Venezuela, over the past 578,000 years: results from redox-sensitive metals (Mo, V, Mn, and Fe)," Paleoceanography, vol. 15, no. 6, pp. 593-604, 2000.

[81] K. Boström, T. Kraemer, and S. Gartner, "Provenance and accumulation rates of opaline silica, $\mathrm{Al}, \mathrm{Ti}, \mathrm{Fe}, \mathrm{Mn}, \mathrm{Cu}, \mathrm{Ni}$ and Co in Pacific Pelagic sediments," Chemical Geology, vol. 11, no. 2, pp. 123-148, 1973.
[82] S. H. Sun, H. Qing, Q. Q. X. Zhang et al., "Sedimentary geochemistry significance of $\mathrm{Sr} / \mathrm{Ba}-\mathrm{V} / \mathrm{NiIn}$ new exploration of Mineral," in Rock and Geochemistry, O. Z. Yuan, Ed., pp. 128130, Earthquake Publishing House, Beijing, China, 1993.

[83] X. H. Li, "Geochemical characteristics of siliceous rock of Northeast Jiangxi Province and its tectonic significances," Science in China D, vol. 30, no. 3, pp. 284-290, 2000.

[84] R. W. Murray, M. R. Buchholtz ten Brink, D. C. Gerlach, G. P. Russ III, and D. L. Jones, "Interoceanic variation in the rare earth, major, and trace element depositional chemistry of chert: perspectives gained from the DSDP and ODP record," Geochimica et Cosmochimica Acta, vol. 56, no. 5, pp. 1897-1913, 1992.

[85] R. W. Murray, M. R. Buchholtz Ten Brink, D. C. Gerlach, G. P. Russ III, and D. L. Jones, "Rare earth, major, and trace elements in chert from the Franciscan Complex and Monterey Group, California: assessing REE sources to fine-grained marine sediments," Geochimica et Cosmochimica Acta, vol. 55, no. 7, pp. 1875-1895, 1991.

[86] P. P. Sun and S. B. Ni, "REE characteristics of basic-ultrabasic rocks from the Jingbulake belt in Xinjiang," Journal of University of Science and Technology of China, vol. 38, no. 4, pp. 347-355, 2008.

[87] H. Shimizu and A. Masuda, "Cerium in chert as an indication of marine environment of its formation," Nature, vol. 266, no. 5600, pp. 346-348, 1977.

[88] H.-Z. Li, Z.-J. Yang, Y.-Z. Zhou et al., "Microfabric characteristics of cherts of Bafangshan-Erlihe $\mathrm{Pb}-\mathrm{Zn}$ ore field in the western Qinling orogen," Earth Science, vol. 34, no. 2, pp. 299306, 2009.

[89] H.-Z. Li, Y.-Z. Zhou, Z.-J. Yang et al., "Diagenesis and metallogenesis evolution of chert in west Qinling orogenic belt: a case from Bafangshan-Erlihe $\mathrm{Pb}-\mathrm{Zn}$ ore deposit," Journal of Jilin University, vol. 41, no. 3, pp. 715-723, 2011.

[90] M. A. Carpenter, E. K. H. Salje, A. Graeme-Barber, B. Wruck, M. T. Dove, and K. S. Knight, "Calibration of excess thermodynamic properties and elastic constant variations associated with the $\alpha-\beta$ phase transition in quartz," American Mineralogist, vol. 83, no. 1-2, pp. 2-22, 1998.

[91] B. Olinger and P. M. Halleck, "The compression of quartz," Journal of Geophysical Research, vol. 81, no. 32, pp. 5711-5714, 1976.

[92] D. Y. Ge, H. X. Tian, and R. G. Zeng, Oryctognosy Concise Tutorial, Geological Press, Beijing, China, 2006.

[93] O. W. Flörke, B. Köhler-Herbertz, K. Langer, and I. Tönges, "Water in microcrystalline quartz of volcanic origin: agates," Contributions to Mineralogy and Petrology, vol. 80, no. 4, pp. 324-333, 1982.

[94] H. Z. Li, Y. Z. Zhou, Z. J. Yang et al., "A study of microarea compositional characteristics and the evolution of cherts from Bafangshan-Erlihe $\mathrm{Pb}-\mathrm{Zn}$ ore deposit in Western Qinling orogen," Earth Science Frontiers, vol. 17, no. 4, pp. 290-298.

[95] Z. Z. Wang, D. Z. Chen, and J. G. Wang, "Element geochemistry and depositional setting of the chert in Devonian, nanning area, Guangxi," Acta Sedimentologica Sinica, vol. 25, no. 2, pp. 239245, 2007.

[96] H. Huang, G. Z. Wang, X. G. Tuo, Y. J. Wang, G. H. Long, and Y. Y. Chen, "Geochemistry characters and geological significance of the late paleozoic chert in jiangnan orogenic belt," Bulletin of Mineralogy Petrology and Geochemistry, vol. 32, no. 5, pp. 567$573,2013$. 
[97] Y. T. Tian, Q. L. Feng, and Q. Li, “The petrogenesis and sedimentary environment of the Bedded cherts from upper permian dalong formation, Southwest Guangxi," Acta Sedimentologica Sinica, vol. 25, no. 5, pp. 671-677, 2007.

[98] K. A. Kormas, M. K. Tivey, K. von Damm, and A. Teske, "Bacterial and archaeal phylotypes associated with distinct mineralogical layers of a white smoker spire from a deep-sea hydrothermal vent site ( ${ }^{\circ} \mathrm{N}$, East Pacific Rise)," Environmental Microbiology, vol. 8, no. 5, pp. 909-920, 2006.

[99] Y. Furukawa and S. E. O’Reilly, "Rapid precipitation of amorphous silica in experimental systems with nontronite (NAu-1) and Shewanella oneidensis MR-1," Geochimica et Cosmochimica Acta, vol. 71, no. 2, pp. 363-377, 2007.

[100] Y.-L. Li, K. O. Konhauser, D. R. Cole, and T. J. Phelps, "Mineral ecophysiological data provide growing evidence for microbial activity in banded-iron formations," Geology, vol. 39, no. 8, pp. 707-710, 2011.

[101] L. Zhang, B. Xia, H. Niu et al., "Metallogenic systems and belts developed on the late Paleozoic continental margin in Xinjiang," Acta Petrologica Sinica, vol. 22, no. 5, pp. 1387-1398, 2006.

[102] Y. Chen, "Fluidization model for continental collision in special reference to study ore-forming fluid of gold deposits in the eastern Qinling mountains, China," Progress in Natural Science, vol. 8, no. 4, pp. 392-393, 1998.

[103] J. C. Zhu, "A brief review for the study on genesis of the submarine volcanic exhalative sedimentary deposits in South China," Geological Journal of China Universities, vol. 9, no. 4, pp. 536-544, 2003.

[104] R. W. Hutchinson, "Volcanogenic sulfide deposits and their metallogenic significance," Economic Geology, vol. 68, pp. 12231246, 1973.

[105] Y. T. Xu, "Early Metallogenic geochemistry in the Yongping CuW Massive sulfide deposit," Geotectonica et metallogenia, vol. 22, no. 1, pp. 55-64, 1998.

[106] L. X. Gu, "Genetic relationship between stratiform manganese ore and lead-zinc veinlets in the Lehua mine," Geological Review, vol. 33, no. 3, pp. 267-274, 1987.

[107] T. Urabe and K. Marumo, "A new model for Kuroko-type deposits of Japan,” Episodes, vol. 14, no. 3, pp. 246-251, 1991.

[108] R. Large, M. Doyle, O. Raymond, D. Cooke, A. Jones, and L. Heasman, "Evaluation of the role of Cambrian granites in the genesis of world class VHMS deposits in Tasmania," Ore Geology Reviews, vol. 10, pp. 215-230, 1996.

[109] L. T. Du, "Sources of ore-forming material and genesis analysis of Yongping copper deposit," Resource Environment \& Engineering, vol. 19, no. 1, pp. 4-11, 2005.

[110] H. Ohmoto, "Stable isotope geochemistry of ore deposits," Reviews in Mineralogy and Geochemistry, vol. 16, pp. 491-559, 1986.

[111] J. Stolz and R. R. Large, "Evaluation of the source-rock control on precious metal grades in volcanic-hosted massive sulfide deposits from Western Tasmania," Economic Geology, vol. 87, no. 3, pp. 720-738, 1992.

[112] S. Y. Wu, Study of Hydrothermal Chimneys in the Mariana Trough, China Ocean Press, Beijing, China, 1995. 

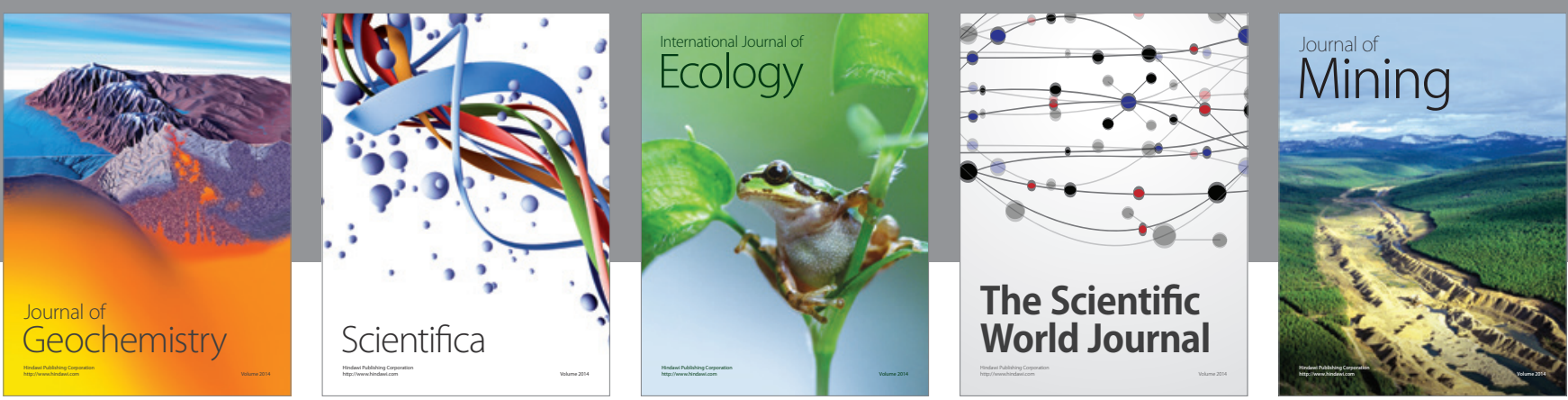

The Scientific World Journal
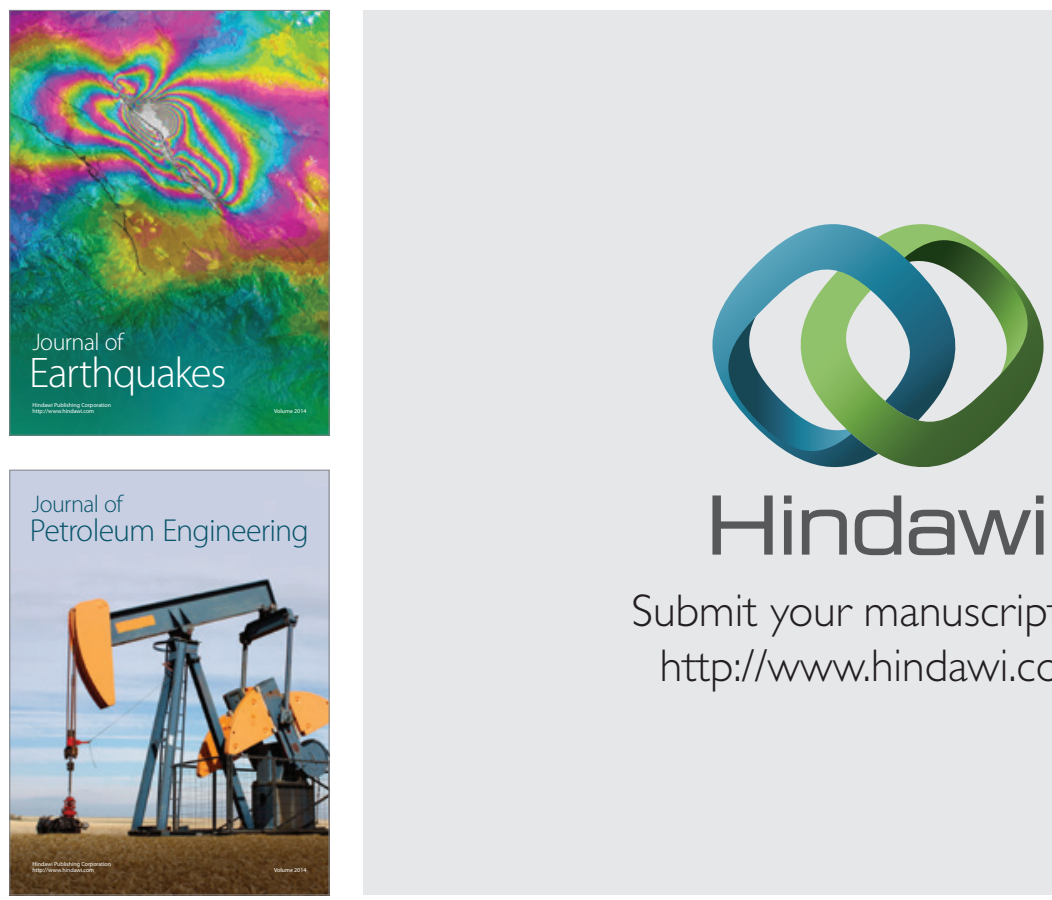

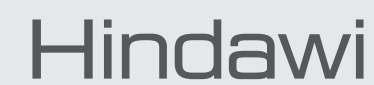

Submit your manuscripts at

http://www.hindawi.com
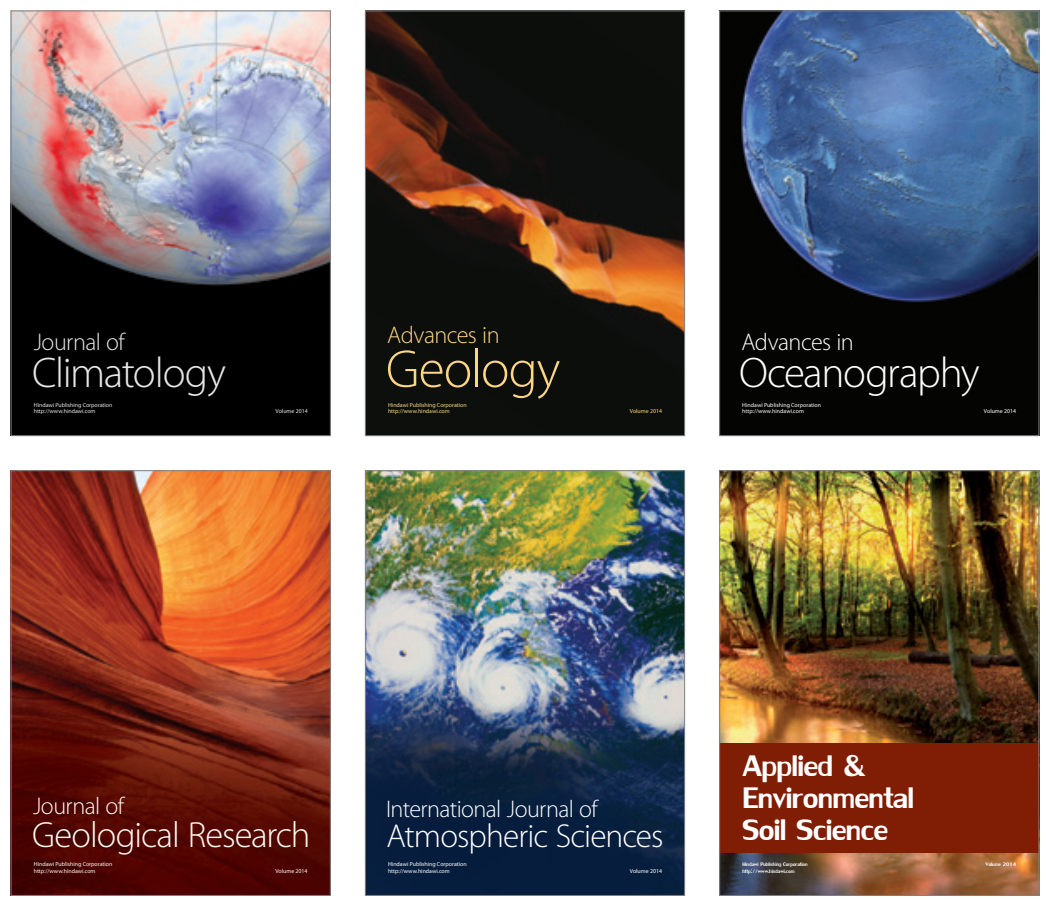
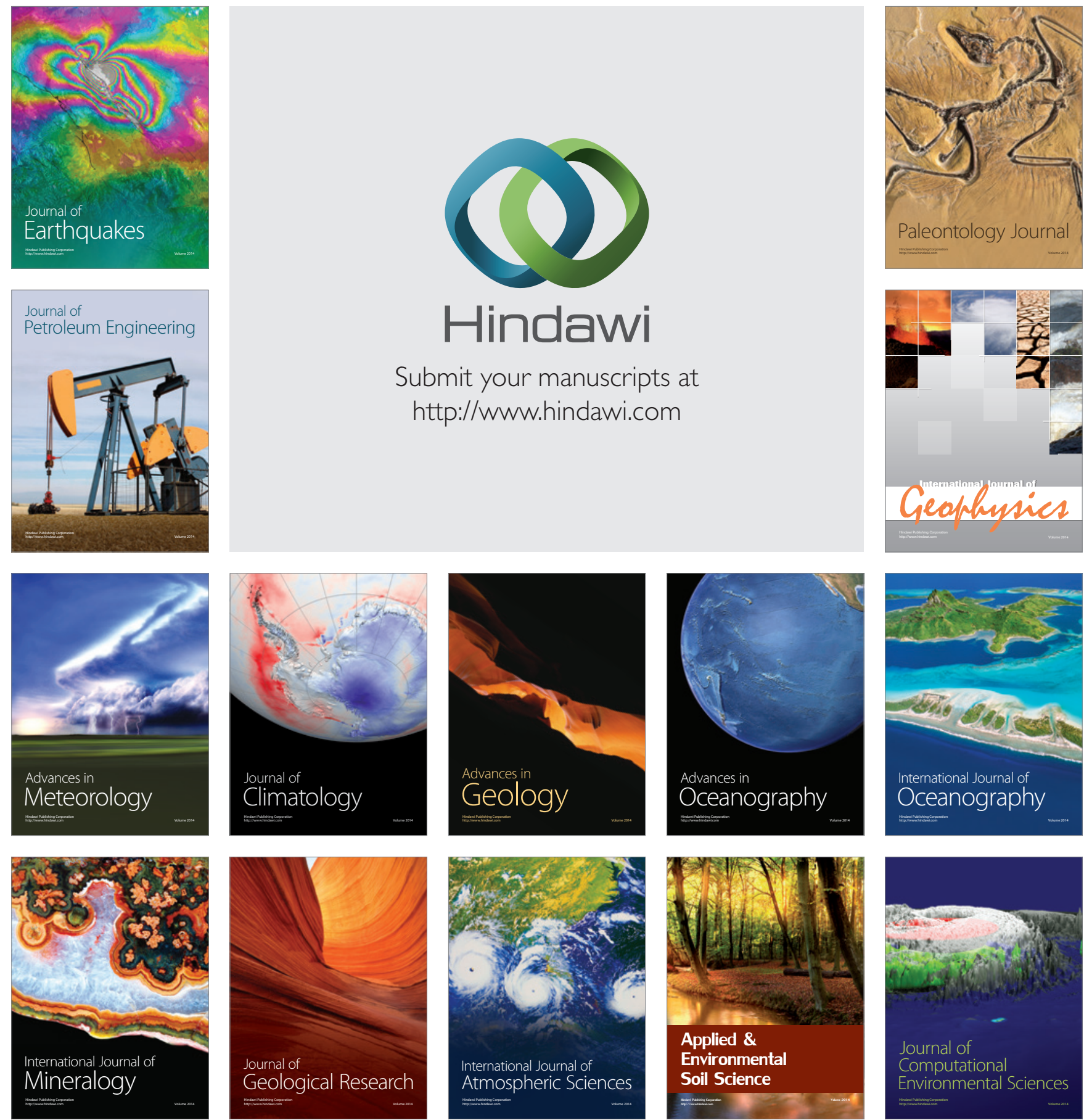